\title{
What are the Opinions of New Zealand Public Library Staff
}

on Ebooks?

by

\section{Megan Adelle Percy}

Submitted to the School of Information Management,

Victoria University of Wellington

in partial fulfilment of the requirements for the degree of

Master of Information Studies

March 2013 


\section{ABSTRACT}

RESEARCH OBJECTIVE: The purpose of this study was to discover the opinions of New Zealand public library staff on ebooks. While there are studies on opinions on ebooks, there is less emphasis on public library staff. Ebooks are becoming more and more popular and how libraries implement them will impact on the future of libraries. The aim of this study was to discover what library staff liked and disliked about ebooks and how they feel about ebooks in public libraries.

METHODOLOGY: Invitations to participate in a survey about ebooks were posted on two email discussion lists, PUBSIG, for New Zealand public library staff, and NZ-Libs, for New Zealand library staff. Additionally, an invitation was emailed to all staff members of Wellington City Libraries. Data were collected using an online survey consisting mainly of Likert-type statements that respondents indicate their level of agreement to. These statements were adapted from previous studies done on ebooks. Respondents were not required to answer every question.

RESULTS: There were 202 responses. 63\% (127) of New Zealand public library staff surveyed have read at least one ebook in the past year. 93\% (188) Agree or Strongly Agree with the statement that it is important for public libraries to offer ebooks. $57 \%$ (105) Agree or Strongly Agree with the statement "I enjoy helping patrons with technical questions about ebooks or ereaders". Respondents think that the portability of ebooks and the ability to customise ebooks is useful. Most library staff surveyed think the increasing popularity of ebooks is good for libraries. The median response to "My library has a great stock of ebooks" was Neither Agree nor Disagree, with the majority of respondents agreeing that ebook licensing terms restricts the stock of ebooks available at their library.

IMPLICATIONS: Library staff think that offering ebooks is important for libraries. However, libraries implementing ebooks need to ensure staff are ready to help patrons with ebooks. Ebook licensing terms are perceived as restricting libraries' ebook stock, for libraries to be successful at offering ebooks the licensing situation may need to change.

DESCRIPTORS: Electronic Books, Librarians, Library Staff, Public Libraries, Opinions 


\section{Table of Contents}

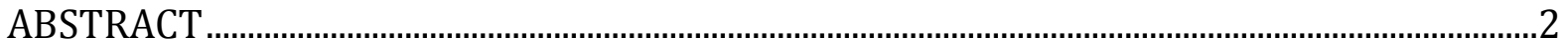

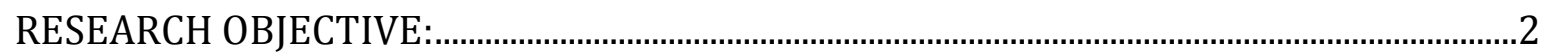

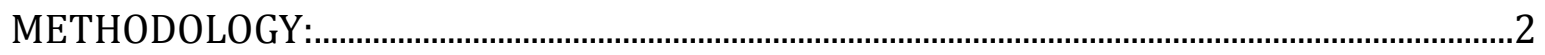

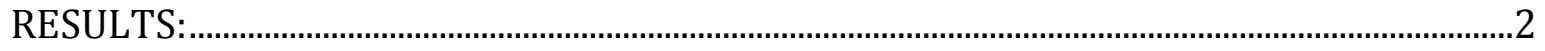

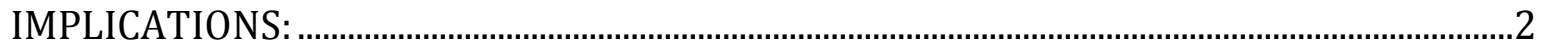

DESCRIPTORS:

INTRODUCTION

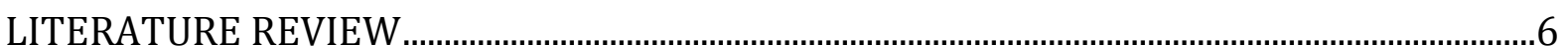

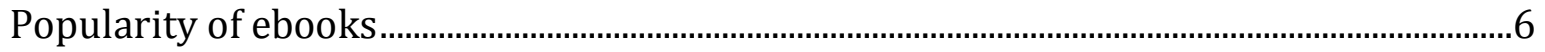

Ebook borrowing in libraries ………........................................................................................

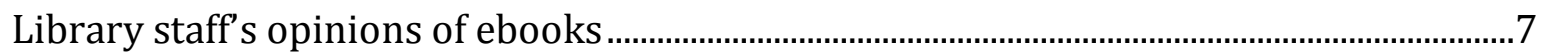

How library patrons discover their library offers ebooks .......................................................8

Problems with ebooks that libraries face

RESEARCH OBJECTIVE AND QUESTIONS ……........................................................................

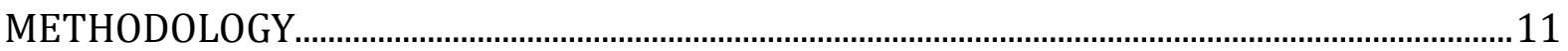

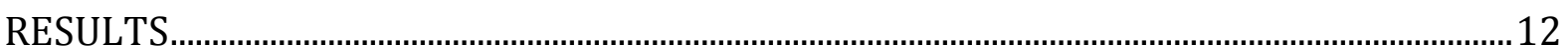

How many ebooks have you read in the past 12 months? .....................................................12

Do you own an ebook reading device? (Specifically for reading ebooks) ..........................13

Does your library offer ebook lending? .....................................................................................13

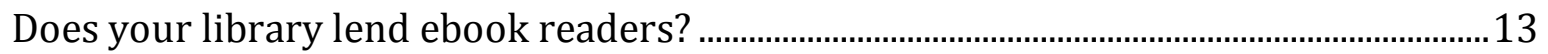

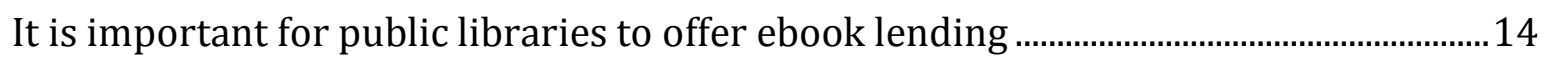

I enjoy helping patrons with technical questions about ebooks or ereaders..................14

The increasing popularity of ebooks is good for libraries......................................................15

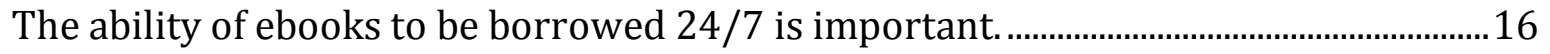

Incompatible ebook file formats are a frequent problem for library patrons..................16

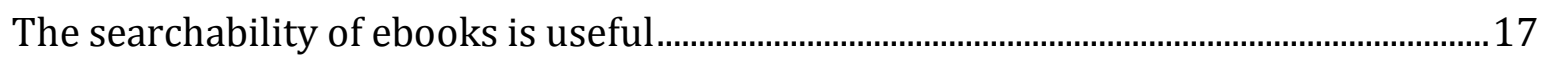

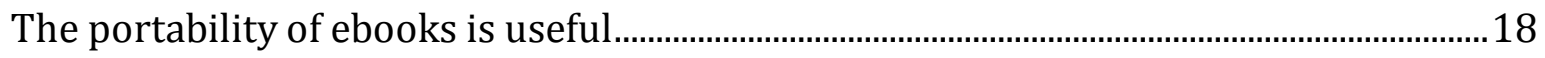

The ability to customise ebooks is useful e.g. change font size, add bookmarks etc.....19

I prefer to read a printed book to an ebook. ................................................................................19

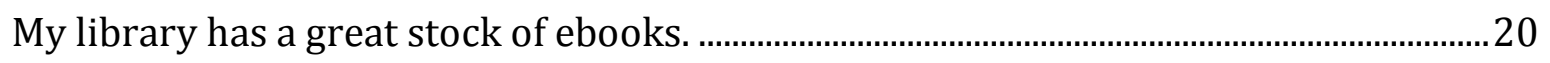

How frequently do you tell patron that your library offers ebooks? .................................21

Ebook licensing terms restricts the stock of ebooks available at my library....................23 
Does your library offer staff training on how to borrow ebooks?

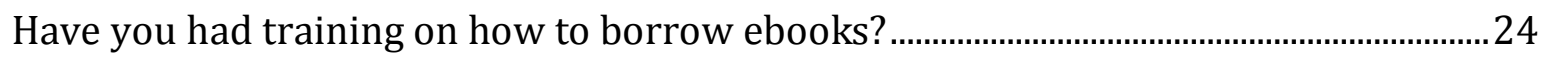

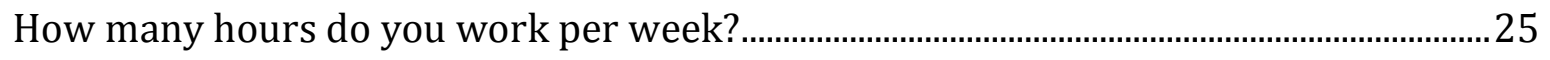

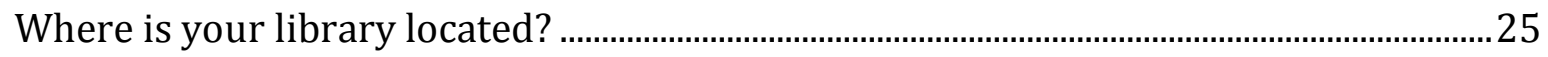

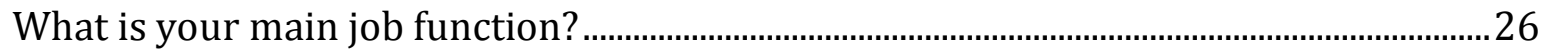

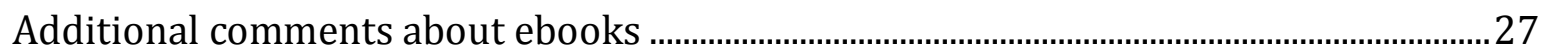

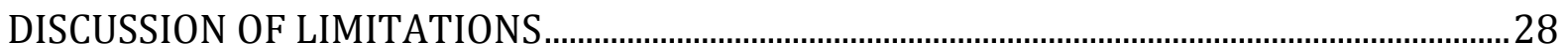

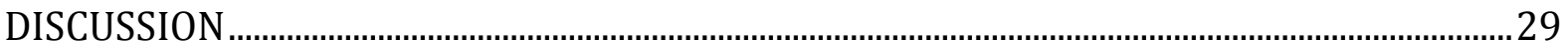

The majority of library staff surveyed have read at least one ebook in the past 12 months

$35 \%$ of library staff surveyed own an ereader specifically for reading ebooks.

$93 \%$ of library staff surveyed work at a library that offers ebooks, $9 \%$ work at a library that lends ereaders.

Library staff surveyed think offering ebooks is important

Many library staff surveyed enjoy helping patrons with technical questions about ebooks or ereaders but not all

Most library staff surveyed think the increasing popularity of ebooks is good for libraries 30

Incompatible file formats. 30

Library staff surveyed think it is important that ebooks can be borrowed anytime ....30

Most library staff surveyed think the searchability of ebooks is useful .............................30

Library staff surveyed think the portability of ebooks is useful ...........................................31

Library staff surveyed think the ability to customise ebooks is useful.

Many library staff surveyed would prefer to read a printed book to an ebook but not all..

Library staff surveyed have varying responses to the statement "My library has a great stock of ebooks.".

Frequency of ebook promotion by library staff surveyed.

The majority of library staff surveyed agree that ebook licensing terms restricts the stock of ebooks available at their library

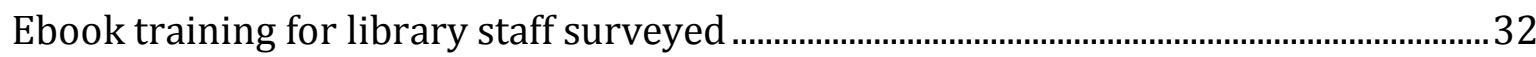

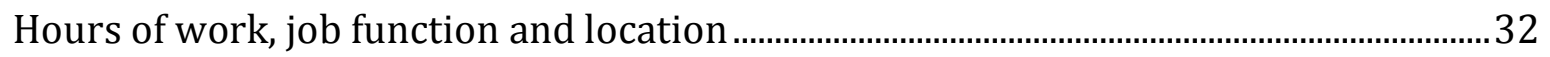

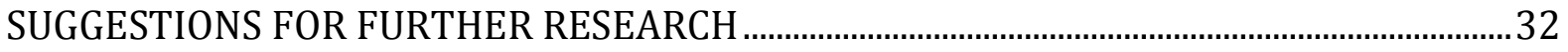


Bibliography

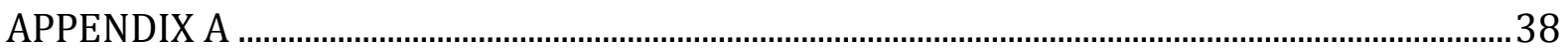

APPENDIX B 


\section{INTRODUCTION}

The purpose of this quantitative self-completion survey was to discover New Zealand public library staff's opinions on ebooks.

The opinions of library staff matter as they promote ebooks, help patrons with technical questions, purchase ebooks and make decisions on how and if ebooks are offered and more.

There are many studies that look at ebook users' opinions on ebooks, some that look at academic librarian's opinions and much fewer on public library staff s opinions. With regards to New Zealand, there appears to be no studies about New Zealand library staff's opinions of ebooks.

By finding out the opinions of New Zealand public library staff, libraries can use this information to help them to decide on their approach to implementing and promoting ebooks, with regards to both staff and the public.

\section{LITERATURE REVIEW}

Relevant literature was found by searching the databases LISA: Library and Information Science Abstracts, Emerald, Library Literature and Information Science Fulltext (H.W. Wilson) and LISTA: Library Information Science \& Technology Abstracts for articles on ebooks. Further articles were found by looking at what sources these articles had themselves used. Google and Google Scholar were also searched.

This literature review looks at the current ebook situation, in terms of ebook popularity and ebooks in libraries. It also looks at opinions on ebooks, what library staff currently think of ebooks and the challenges they face with them.

\section{Popularity of ebooks}

The popularity of ebooks continues to grow.

The Association of American publishers estimated that ebook sales rose 117\% in 2011, based on publishers that report sales to them. (Publishers Weekly, 2012).

23\% of American adults over the age of 16 have read an ebook in the past year, up from $16 \%$ the year before. (Rainie \& Duggan, 2012).

In late 2012, 19\% of Americans aged 16 and older own ebook reading devices specifically for reading ebooks, compared with $10 \%$ a year before that. (Rainie \& Duggan, 2012).

According to "The Fourth Annual eBook Survey of Publishers" from Aptara (2012) 4 out of 5 publishers surveyed now produce eBooks - a 30\% increase in three years. Also, the survey found that "the majority of publishers now produce more than $50 \%$ of their titles as eBooks". (Aptara, 2012). 
As ebook popularity increases this will likely lead to an acceptance of ebooks as a mainstream media, leading to an expectation that public libraries offer ebook lending.

\section{Ebook borrowing in libraries}

Ebook borrowing is still a small part of overall circulation however it has been growing rapidly.

Ebook circulation only accounted for two percent of circulation on average in 2011 in the USA, compared to 67 percent for books and 29 percent for media. (Hoffert, 2012).

Despite only being two percent of circulation, ebook circulation in public libraries doubled from 2009 to 2010 and quadrupled from 2010 to 2011. (Library Journal, 2012).

$5 \%$ of recent public library users in America borrowed an ebook this year, compared with 3\% last year. (Rainie \& Duggan, 2012).

According to the Book Industry Study Group's fourth volume of "Consumer Attitudes Toward E-Book Reading", 11\% of people who read ebooks use libraries to borrow them. (Reid \& Milliot, 2012).

The American Library Association found in their 2011 - 2012 Public Library Funding \& Technology Access Study that 76\% of American public libraries offer access to ebooks and 39\% of them lend e-readers. (Hoffman, Bertot, \& Davis, 2012).

The full impact is yet to be felt however as many library users do not know if their library offers ebook lending. Zickuhr, Rainie, Purcell, Madden and Brenner (2012) found that 58\% of American library card holders did not know if their library had ebooks available for borrowing.

\section{Library staff's opinions of ebooks}

As ebook popularity increases, the effect and impact on libraries must be considered.

Zickuhr et al. (2012) found that the majority of public American librarians surveyed "thought that the evolution of e-book reading devices and digital content has been a good thing for libraries" although many librarians are often "anxious about the new set of demands on them to learn about the operations of new gadgets, to master every new web application, and to de-bug every glitch on a digital device".

OCLC (2011) found for American public library staff that providing access to ebooks is a top priority.

Chief Officers of State Library Agencies [COSLA] (2010) in its interviews with libraries leaders found that most of their respondents "felt eBooks will increasingly attract or keep library patrons who like this format or desire convenience". 
Vasileiou and Rowley (2010) conducted qualitative interviews with librarians about ebook promotion in academic libraries. They found a significant reason librarians are reluctant to promote ebooks is lack of ebook stock. Additionally, some librarians were concerned that "the promotion of e-books can undermine perceptions of the value of print books". (p. 635).

Salomon (2009) in his masters' paper surveyed North Carolina librarians from public libraries for their opinions on ebooks and their usage of ebooks. He found that the librarians generally liked ebooks, and three of the main things librarians liked were their ability to be checked out instantly, their portability and their potential for interactivity and customisation.

\section{How library patrons discover their library offers ebooks}

Library patrons frequently find out about ebooks from librarians. eBrary (2008) in their worldwide survey of university students found that $50 \%$ of the university students discovered that their libraries offered ebooks from a librarian.

In contrast, Borchert, Hunter, McDonald and Tittel (2009) in their study of two Queensland universities found that $17 \%$ of students discovered their libraries offered ebooks from a librarian while $42 \%$ of students discovered ebooks through their library catalogue. This means that libraries that do not have ebooks integrated into their catalogue would need to particularly promote the fact that they offered ebooks to patrons.

\section{The advantages and disadvantages of ebooks for users}

Duncan (2010) surveyed public library users in Sunshine Coast, Australia. He found that $79 \%$ of ebook users used them because they were more portable/easier for travelling.

Richardson and Mahmood (2012) in their study "eBook readers: user satisfaction and usability issues" which surveyed graduate information studies students found the most popular feature of ereaders generally was the portability they offered.

Staiger (2012) in his literature review of ebook usage in academic settings found that library patrons thought the two main benefits of ebooks were searchability and 24/7 availability. He found "the most frequently cited disadvantages were difficulty of navigation and loss of ability to perform customary research practices such as perusing and shelf-browsing because of e-books' lack of physicality." (p. 355).

Borchert et al (2009) found that the university students surveyed generally liked ebooks. Like Staiger identified, the things they liked most about ebooks were their 24/7 accessibility and their ability to be searched. They also liked the ability to copy and paste. 


\section{Problems with ebooks that libraries face}

In the Library Journal's "Ebook Usage in U.S. Public Libraries", librarians were asked, "What hinders the public from accessing your ebook collection? The top four reasons given were, long wait times for ebooks (72\%), limited titles available (71\%), in demand titles not available for libraries (60\%) and complex downloading process (55\%). (Library Journal, 2012)

COSLA (2010) in its interviews with library leaders found that all "all agreed that getting eBooks from libraries is not convenient or easy to do. "(p. 10). The problems they found was that firstly, it is hard to explain that even though an ebook is digital, that the one copy, one user model of print books can still apply. Secondly, the library leaders outlined that it is cumbersome for patrons to wade through layers of a library website to find ebooks, then to be able to download the ebooks they must have the appropriate software installed and following this they have to transfer them to their ereading device.

It is worth noting, that while the above problems are still relevant, some libraries now have their ebook collection integrated into their catalogue. This saves patrons from excessive navigation through a library website. Also, some patrons have devices that ebooks can be downloaded directly on to, such as the iPad rather than having to be transferred via computer.

COSLA (2010) also noted that library leaders are concerned that as most libraries' public computers cannot be used to download ebooks, this limits the ability to borrow ebooks to patrons with both the internet and the appropriate hardware, widening the digital divide.

The digital divide concern identified by the COSLA study above is a relevant one, as Rainie and Duggan (2012) identified "those most likely to read e-books include those with college or graduate degrees, those who live in households earning more than $\$ 75,000$, and those whose ages fall between 30 and 49." (p. 3).

Another problem associated with ebook borrowing is that the format offered may not be compatible with the patron's ereader. Zickuhr et al. (2012) found that $18 \%$ of e-book borrowers had previously been unable to borrow the ebook they wanted because although the ebook was available, it was not available in a compatible file format for them.

In New Zealand, the Amazon Kindle ereader is not compatible with Overdrive ebooks (OverDrive, 2013) or with Wheelers ebooks. There does not appear to be a comprehensive list of compatible ereaders on the Wheelers website, however New Zealand public libraries that do offer ebooks from Wheelers outline on their websites that Kindles are not compatible with them, for example on the Waimakiriri District Library website (Waimakariri, n.d.). 
Additionally, licensing restrictions imposed by publishers can make purchasing ebook difficult for libraries.

There are six big publishing companies. Two of these, Simon \& Schuster and MacMillan, do not sell ebooks to libraries, and do not allow libraries to lend their ebooks. (Zickuhr et al., 2012).

Penguin is currently trialling a library ebook lending system where libraries cannot purchase ebooks until six months after their release and the ebook lending license expires after one year. (Maloney, 2012)

Hachette is also trialling a new ebook lending system, although they currently do sell their backlist to libraries, their backlist being titles published before April 2010. (Raphael, 2012).

HarperCollins has a loan cap of 26 times, after which the library needs to repurchase it if they wish to keep offering it. (Hadro, 2011).

Random House allows libraries unrestricted purchasing access to all of its ebooks, however it increased its prices to libraries in 2012. (Kelley, 2012 ).

\section{RESEARCH OBJECTIVE AND QUESTIONS}

The objective of the research project was to attain New Zealand public library staff's opinions on ebooks, in particular, the current ebook situation, the qualities of ebooks, and importantly, ebooks in libraries.

By learning more about their opinions, this allows libraries to focus and potentially change how ebooks are introduced to staff and to identify any potential issues that library staff have with ebooks that can be addressed.

The main question researched is "What are public library staff's opinions on ebooks?

Within this broad question, opinions about the themes taken from the literature review were examined. This research project looks library staff's opinions on:

The importance of public libraries offering ebooks

Technical questions about ebooks

The increasing popularity of ebooks and libraries

Ebooks' searchability, portability, 24/7 availability and ability to be customised

Ebook stock in their library

Printed book compared to ebook preference

This research project also looks at: 
If library staff read ebooks

Whether they own e-readers

How frequently they tell patrons that their library offers ebooks

Further relevant issues or topics not identified by the survey. This is achieved by the inclusion of a textbox where survey respondents can add any additional comments.

\section{METHODOLOGY}

Davidson and Tolich (2003) outline that patterns drawn from quantitative data can be generalised to a wider group. They also outline that quantitative research methods allow the opinions of large numbers of people, spread over large areas, to be collected in one go. As this research project is looking at the opinions of New Zealand public librarians as a whole, a quantitative approach is appropriate.

Based on the literature review a series of radio-button questions and Likert-type statements about ebooks were developed. "Likert-type scales are used to quantify results and obtain shades of perception. Choices (or categories of responses) usually range from strongly disagree to strongly agree." (Simon, 2011). All of the responses to a statement can then be looked at to see what a group's overall attitude to that statement was.

There was also a text box question at the end of the survey where people could add additional comments if they so wished.

The design also allowed the survey to be completed quickly, as survey respondents are more likely to respond to a request to do an online survey if the estimated time is 8-10 minutes compared to 20 minutes. (Crawford, Couper, \& Lamias, 2001). The estimated completion time for this survey was 10 minutes based on the fact it was 23 questions, 22 of which were closed.

The survey was made using the survey tool Qualtrics. The survey is below at Appendix A.

An email inviting New Zealand Public Library staff to participate in the survey was emailed to the members of the NZ-Libs and PUBSIG email discussion groups and also to all staff members at Wellington City Libraries. NZ-Libs discusses library and information services in New Zealand. (NZ-Libs). PUBSIG discusses issues relating to New Zealand Public Libraries. (Library Association of New Zealand Aotearoa). The email is below at Appendix B.

The survey was available from the $12^{\text {th }}$ of December 2012 to the $28^{\text {th }}$ of December 2012. 
The participants' email addresses were downloaded to an Excel sheet separately first, to randomly select a winner for the voucher that was offered as incentive to complete the survey. Once the winner was emailed the spread sheet was deleted.

Then the email addresses were deleted from Qualtrics. The remaining results, minus the email addresses, were downloaded to an Excel spread sheet for data analysis.

Graphs were created in Excel to visually compare the distribution of responses, as well as looking at the medians and percentages of the responses. The graphs looked at percentages of respondents, rather than number of respondents, to allow easier comparison between the questions and statements.

To see visually if relationships existed between some of the questions, data from some questions were used to categorise data from others, and then graphed.

The additional comments from the text box question were analysed to draw larger overall themes from them.

\section{RESULTS}

There were 203 respondents to this survey. Not every respondent answered every question. One response was deleted as they noted in their comments they were a school librarian and as such their response may differ from that of public library staff.

The median response time was three minutes however the mean response time was six minutes as there were four responses that took over an hour to complete. Based on the length of time taken, it is unlikely that those four respondents worked continuously on this survey.

\section{How many ebooks have you read in the past 12 months?}

There were 202 responses to this question. 37\% (75) of respondents have not read an ebook in the past 12 months compared to $63 \%$ (127) that have read at least one.

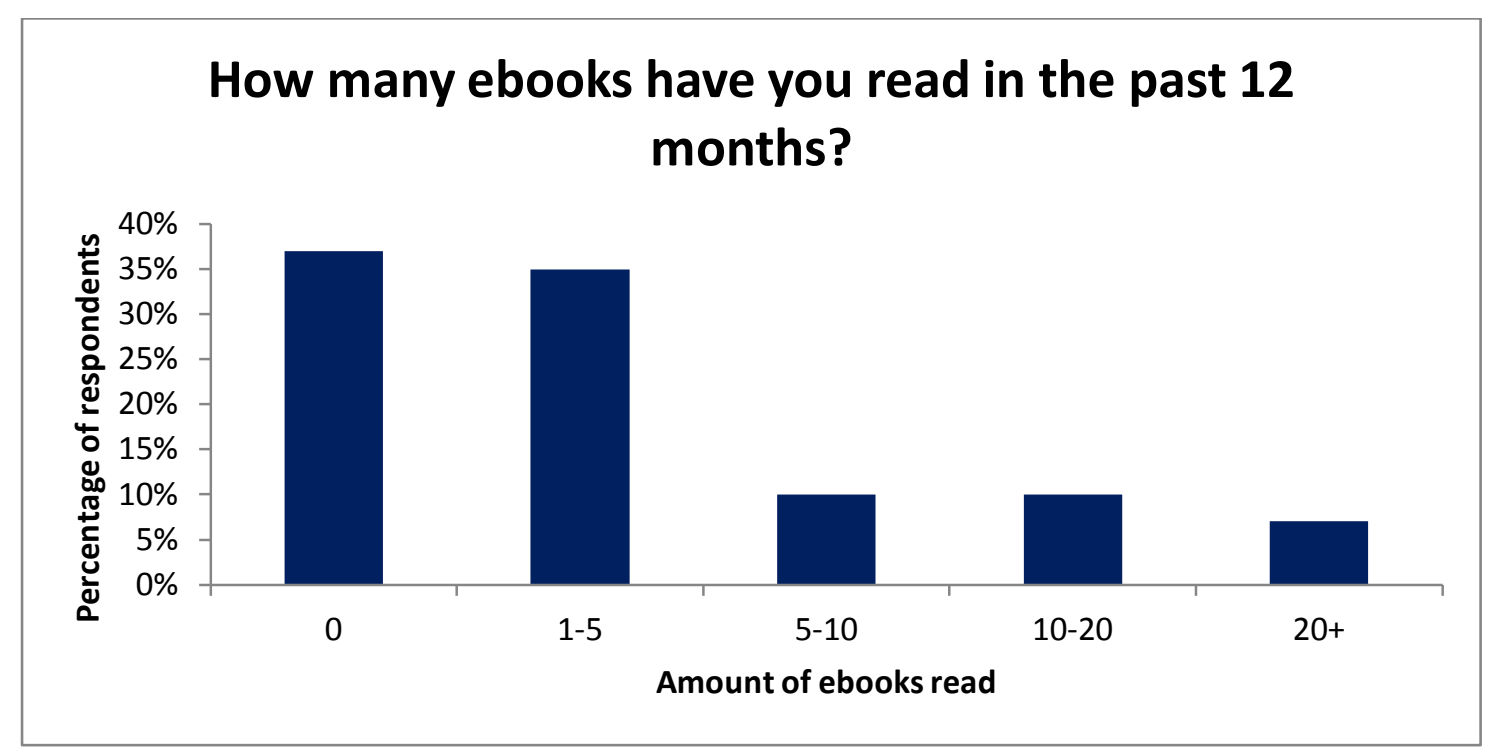




\section{Do you own an ebook reading device? (Specifically for reading ebooks)}

There were 198 responses to this question. 35\% (70) of respondents answered Yes, and $65 \%$ (128) respondents answered No.

These responses were used to categorise data from the question regarding amount of ebooks read in the past 12 months.

$55 \%$ (70) of respondents who did not own an ebook reading device had not read any ebooks in the past 12 months whereas only 4\% (3) of those who owned an ebook reading device had not read any ebooks in the past 12 months.

$50 \%$ of respondents who owned an ebook reading device have read more than 5 ebooks in the past year whereas $15 \%$ of respondents who do not own an ebook reading device have read more than 5 ebooks in the past year.

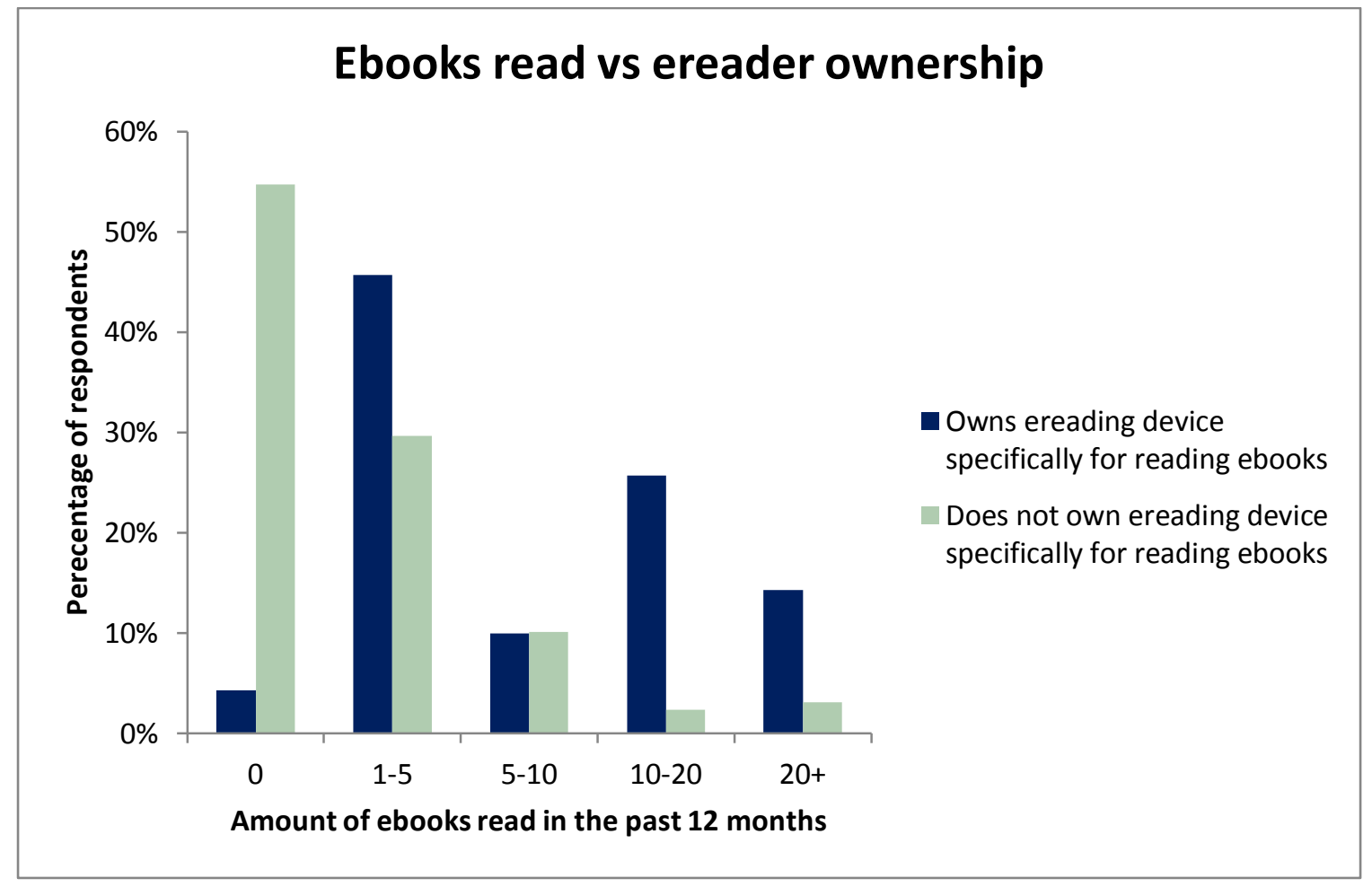

\section{Does your library offer ebook lending?}

There were 201 responses. 93\% (186) of respondents answered Yes, 6\% (12) answered No and 1\% (3) answered I don't know.

\section{Does your library lend ebook readers?}

There were 199 answers. 9\% (17) of respondents answered Yes, 90\% (179) answered No and 2\% (3) answered I don't know. 
It is important for public libraries to offer ebook lending

There were 202 responses this question. The median response was Strongly Agree. 93\% (188) of the responses were Agree or Strongly Agree.

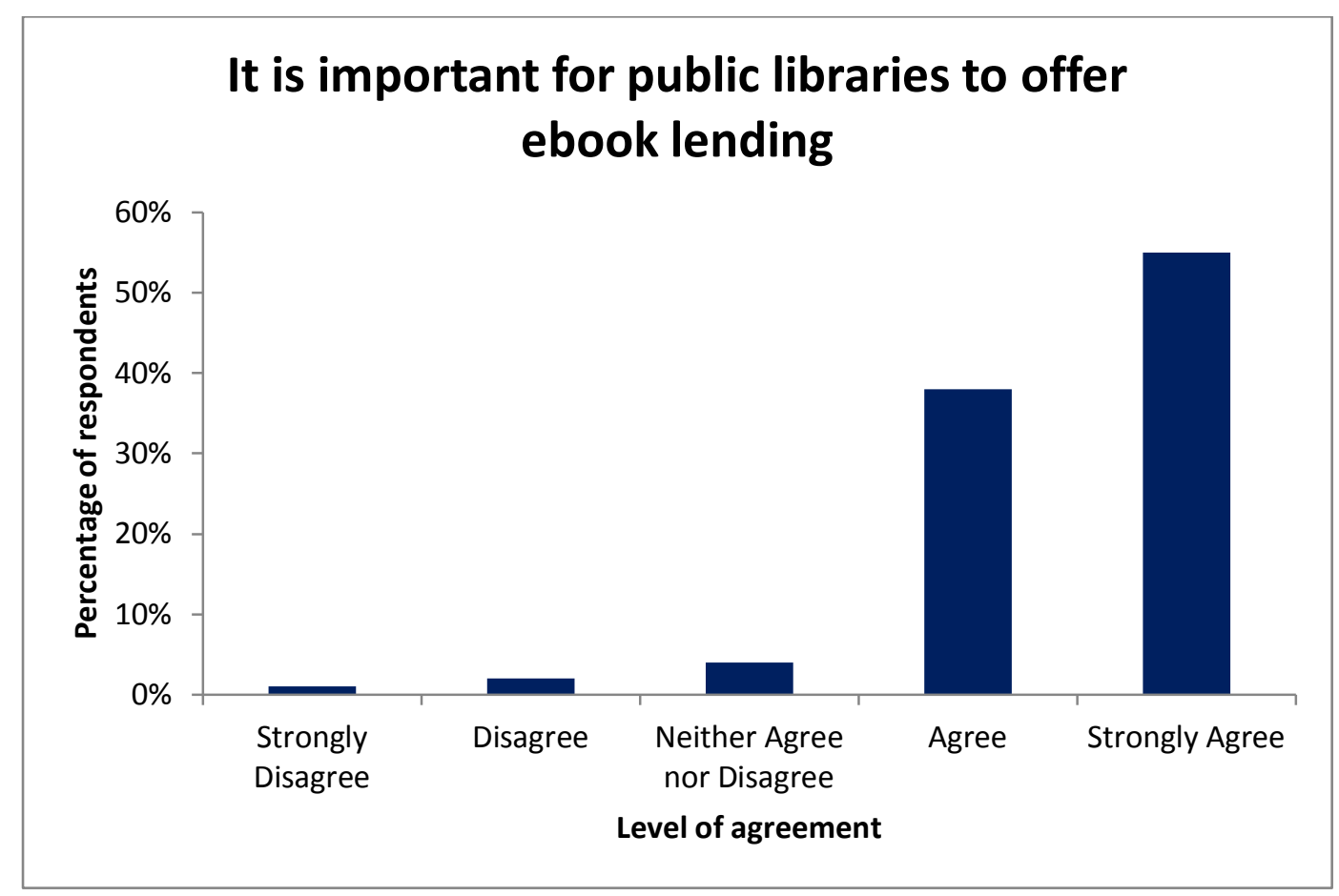

I enjoy helping patrons with technical questions about ebooks or ereaders. Looking at only respondents from libraries that offered ebooks, there were 184 responses.

While the median answer was Agree there was a big spread in the distribution of responses. 5\% (9) answered Strongly Disagree , 18\% (33) Disagree, 20\% (37) Neither Agree nor Disagree, 41\% (75) Agree, and 16\% (30) Strongly Agree.

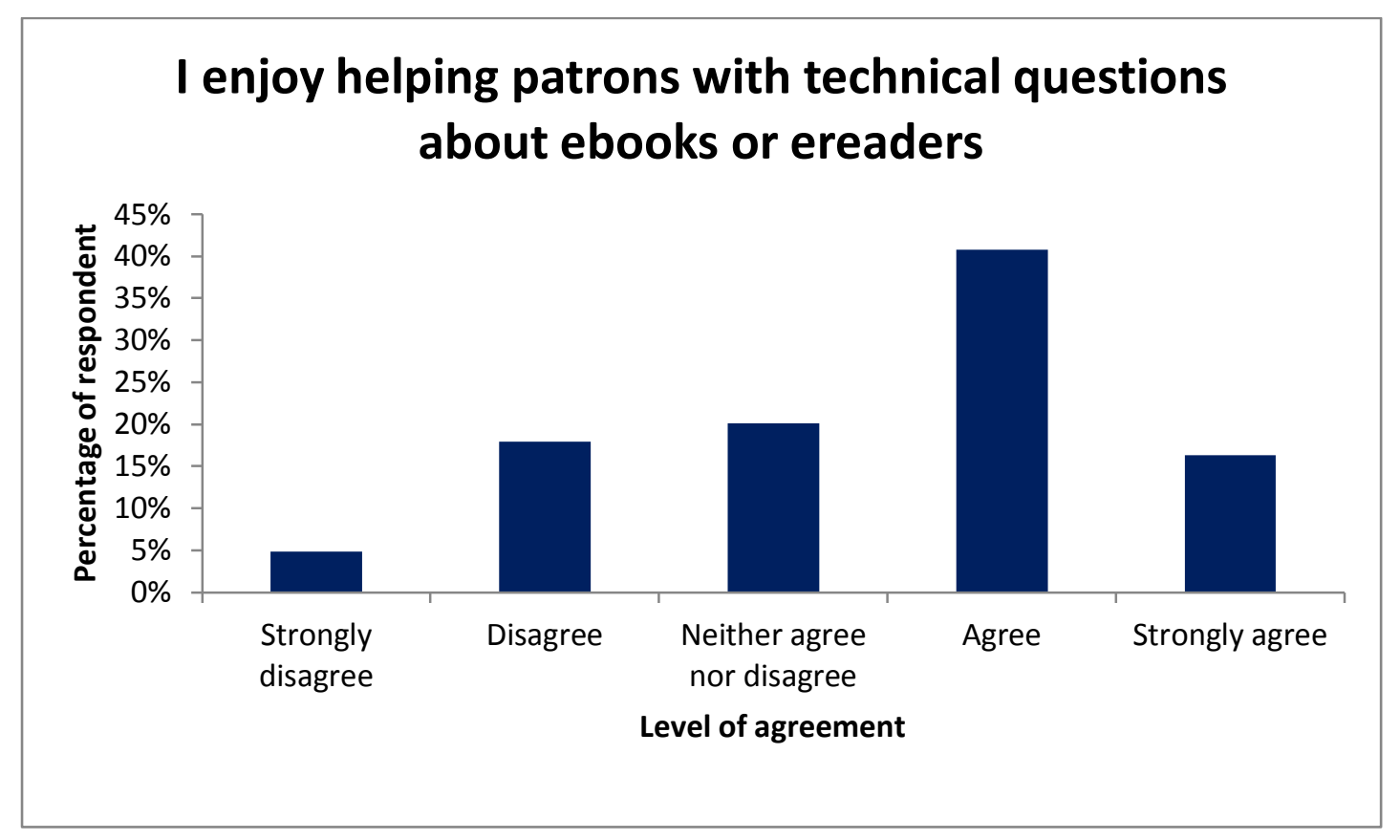


The below graph looks at whether there is a relationship between ownership of an ereader specifically for ebooks and agreement to the statement "I enjoy helping patrons with technical questions about ebooks and ereaders".

Those survey respondents who own ereaders answered Agree or Strongly Agree to the statement more often.

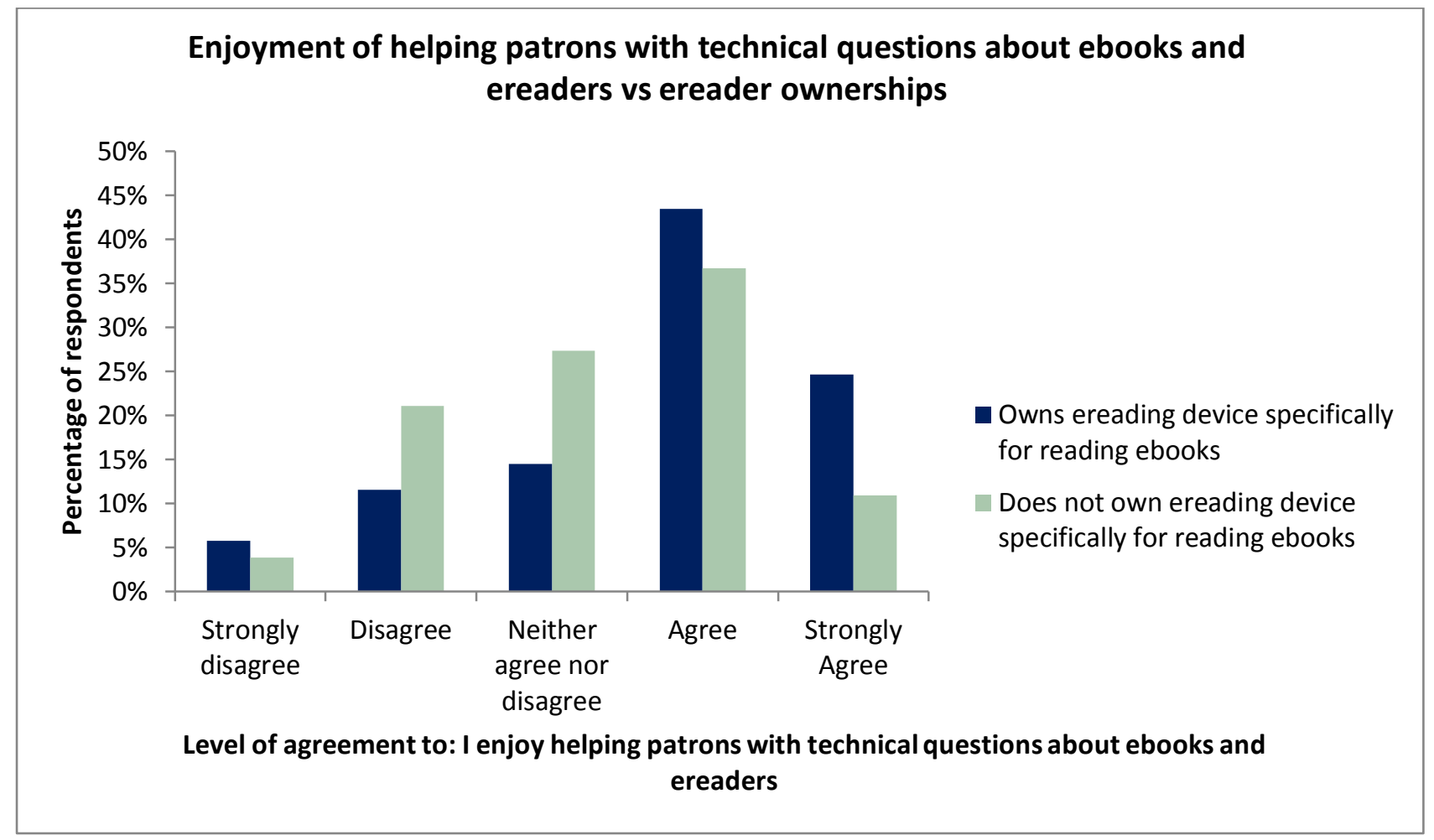

The increasing popularity of ebooks is good for libraries

There were 199 responses to this question. While the median answer is Agree, more respondents answered Neither Agree nor Disagree with the statement than answered Strongly Agree with it.

No respondents answered Strongly Disagree to this statement, 7\% (14) answered Disagree, 32\% (64) Neither Agree nor Disagree, 40\% (79) Agree and 21\% (42) Strongly Agree. 


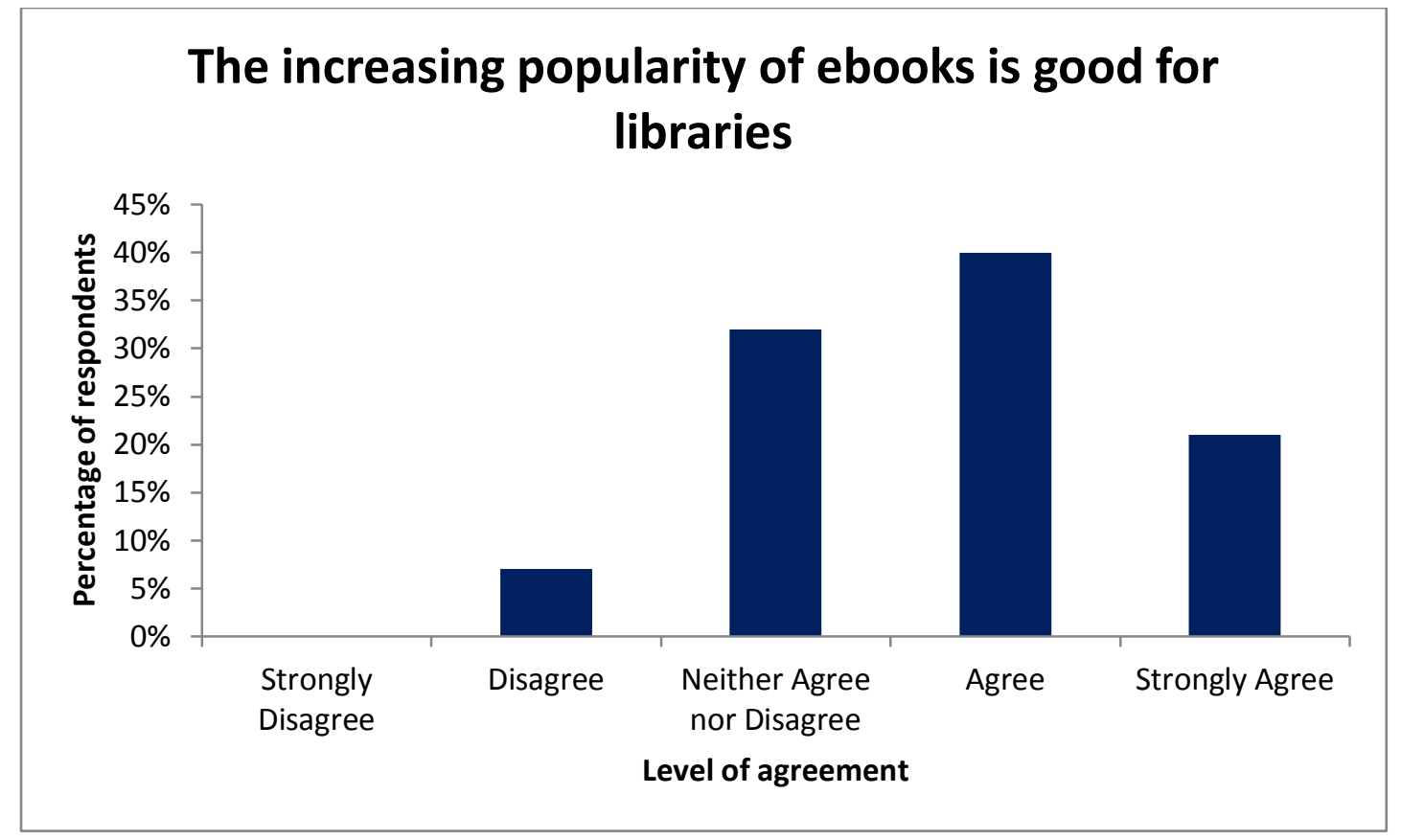

The ability of ebooks to be borrowed $24 / 7$ is important.

There were 198 responses to this question. The median fell between Agree and Strongly Agree. 91\% (181) of respondents answered Agree or Strongly Agree to this statement.

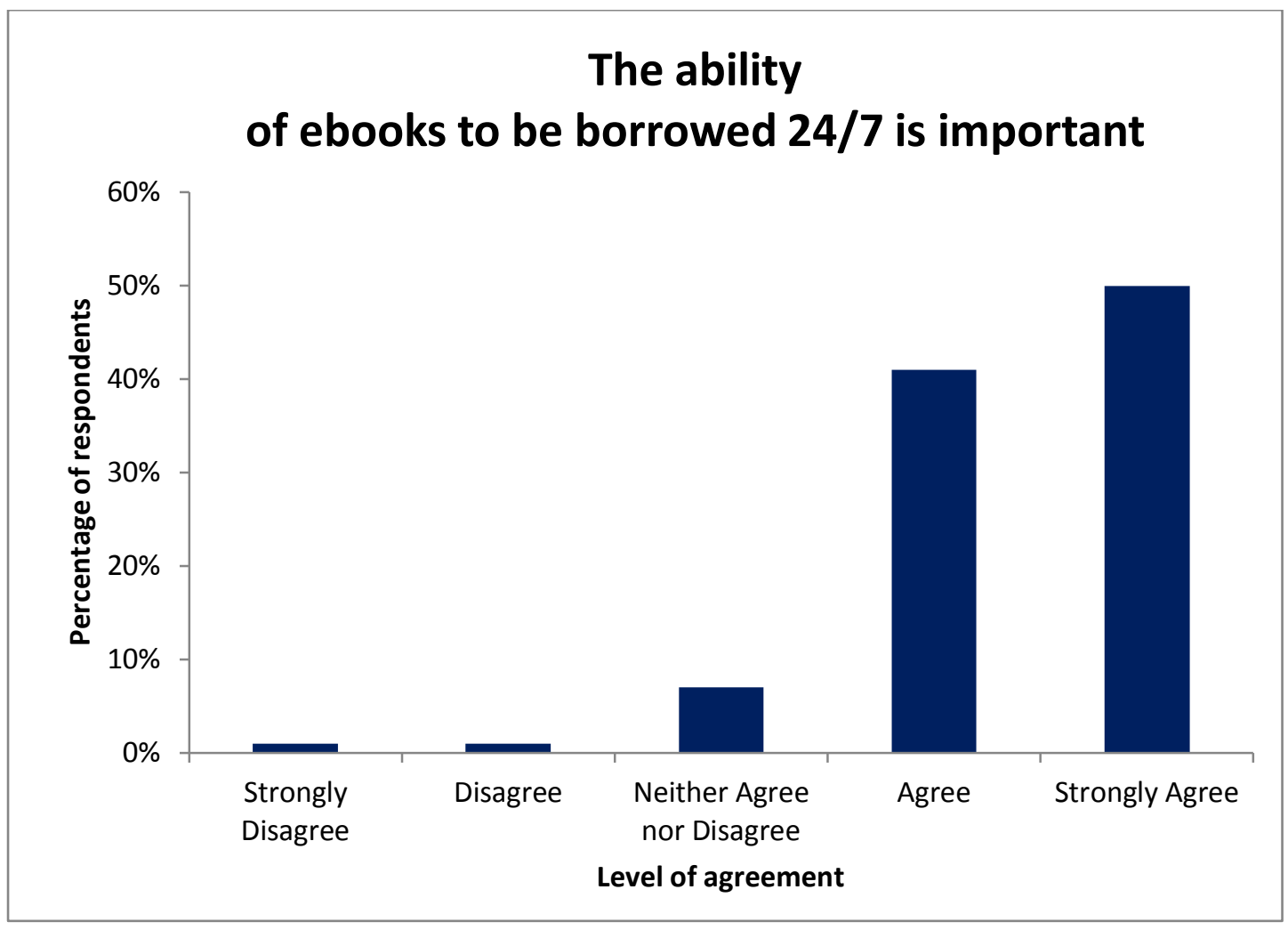

Incompatible ebook file formats are a frequent problem for library patrons Looking at only respondents from libraries that offered ebooks, they were 185 responses. The median response is Agree. 58\% (116) of respondents answered Agree or Strongly Agree to this statement. 


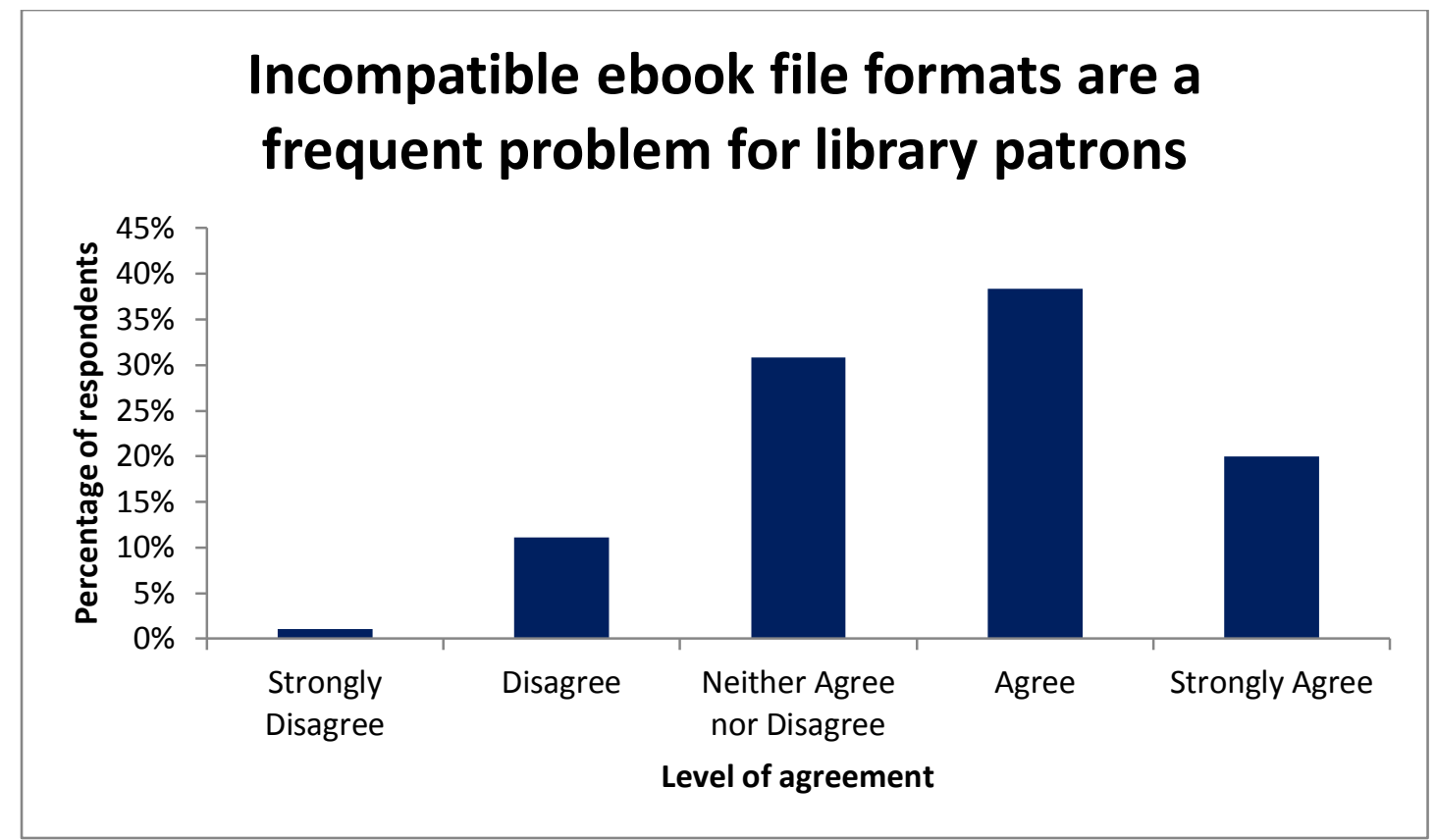

The searchability of ebooks is useful

There were 200 responses to this statement. The median response is Agree. 76\% (150) of respondents answered Agree or Strongly Agree.

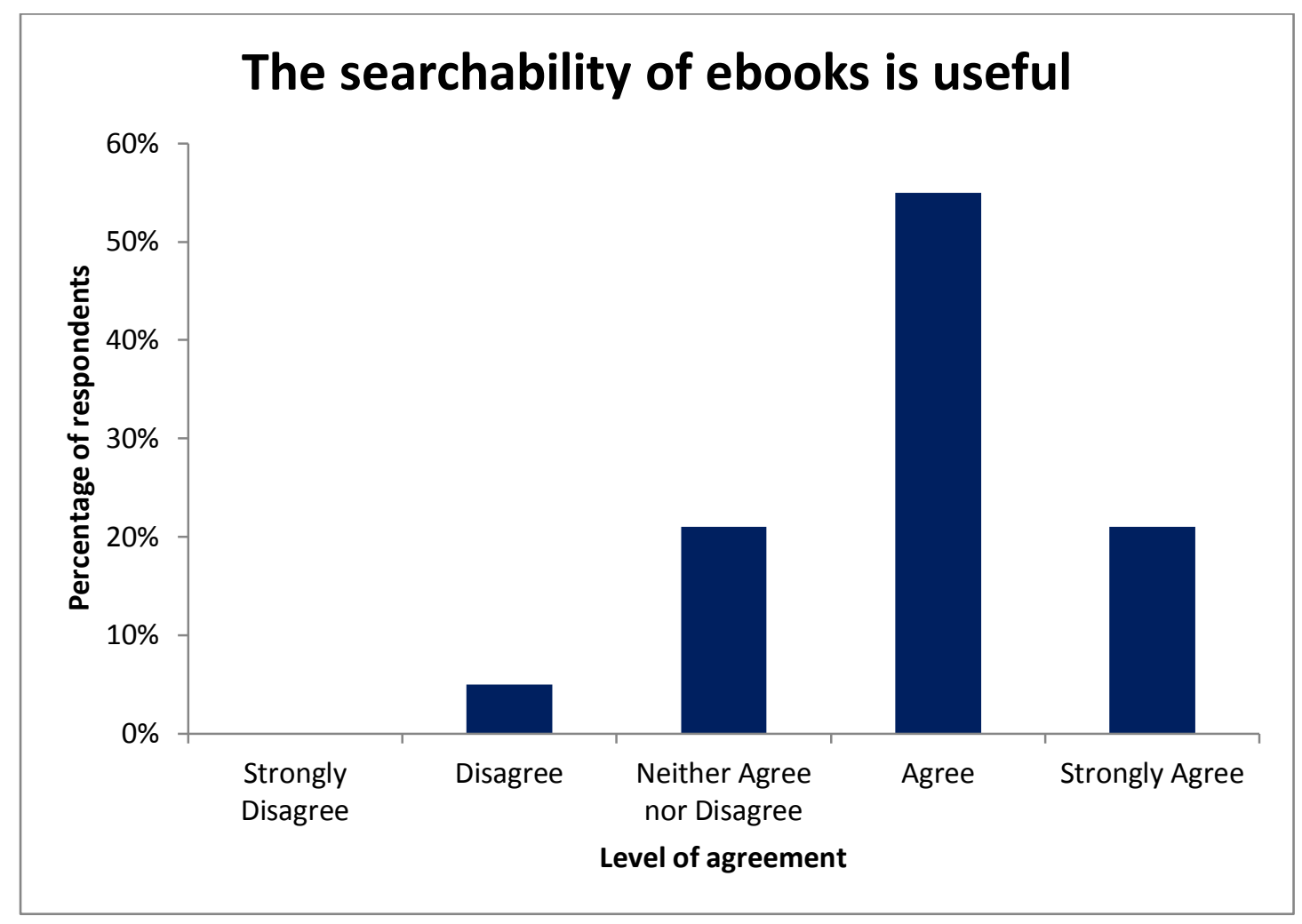


The portability of ebooks is useful

There were 198 responses to this question. The median response was Strongly Agree. 96\% (190) of respondents answered either Agree or Strongly Agree to this statement. Only 4\% (8) answered neither Agree nor Disagree and no respondents disagreed with this statement.

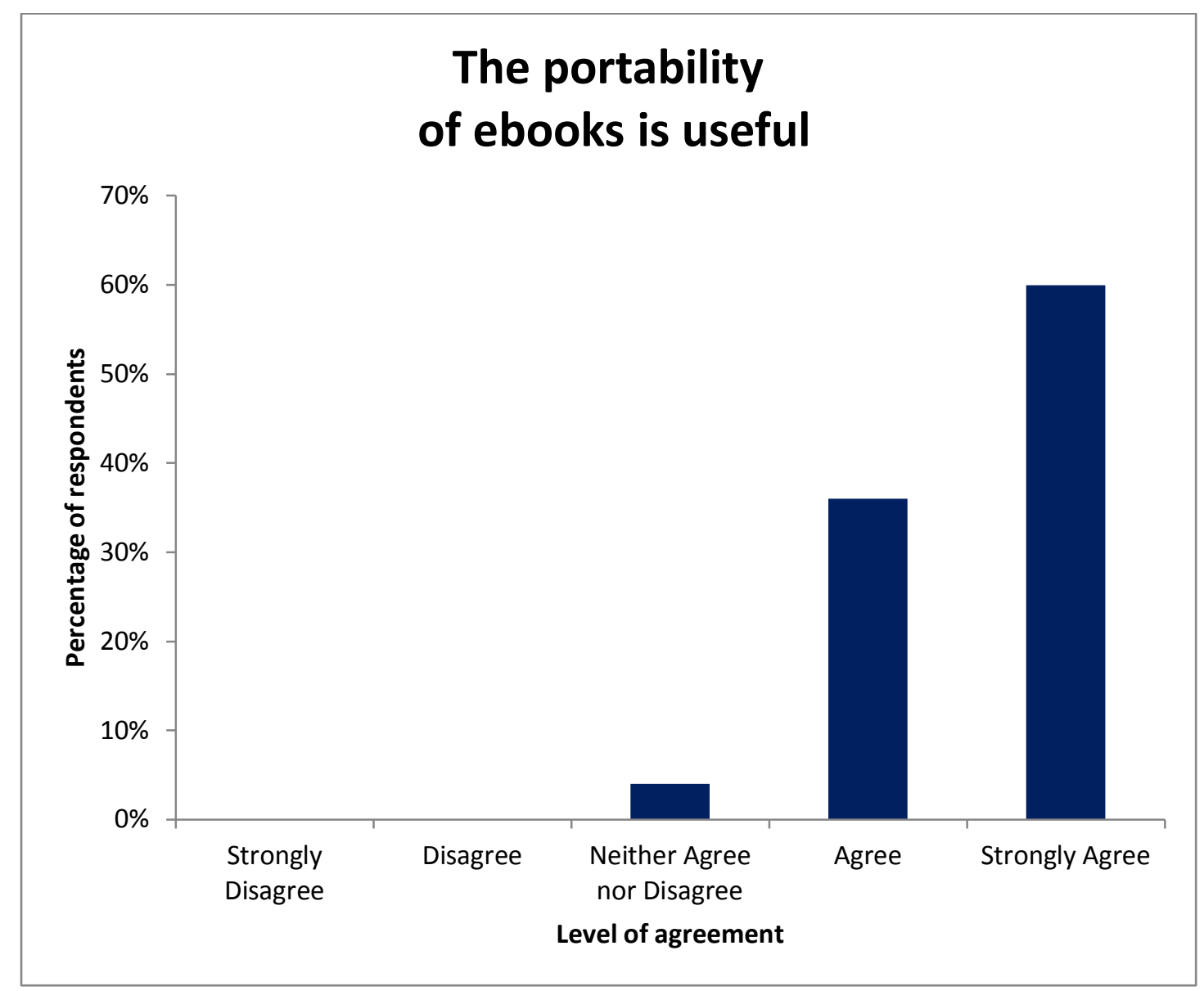


The ability to customise ebooks is useful e.g. change font size, add bookmarks etc There were 199 responses to this statement. The median was Strongly Agree. 95\% (188) of respondents answered Agree or Strongly Agree to this statement.

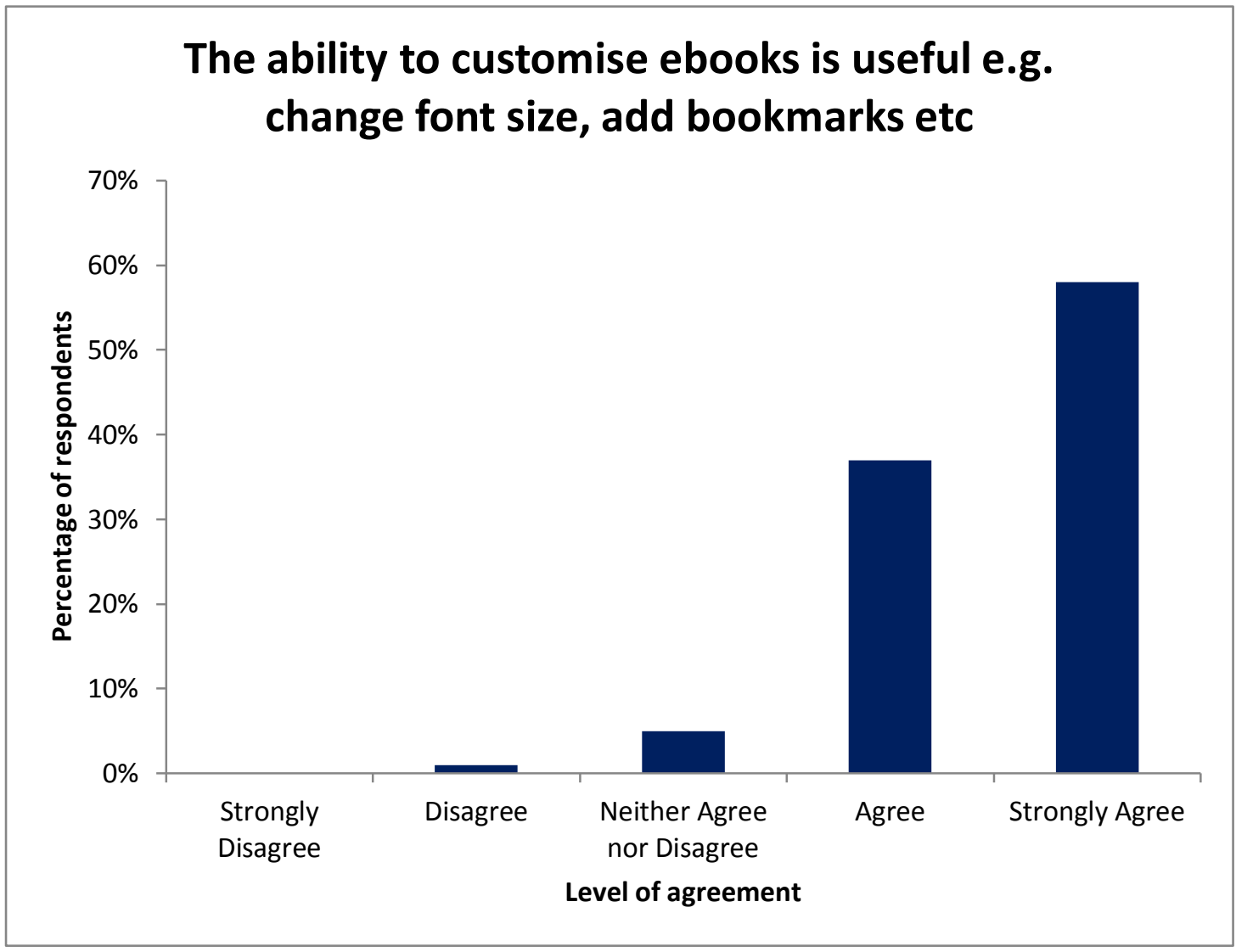

I prefer to read a printed book to an ebook.

There were 198 responses to this statement. The median response was Agree. 66\% (130) of respondents either answered Agree or Strongly Agree.

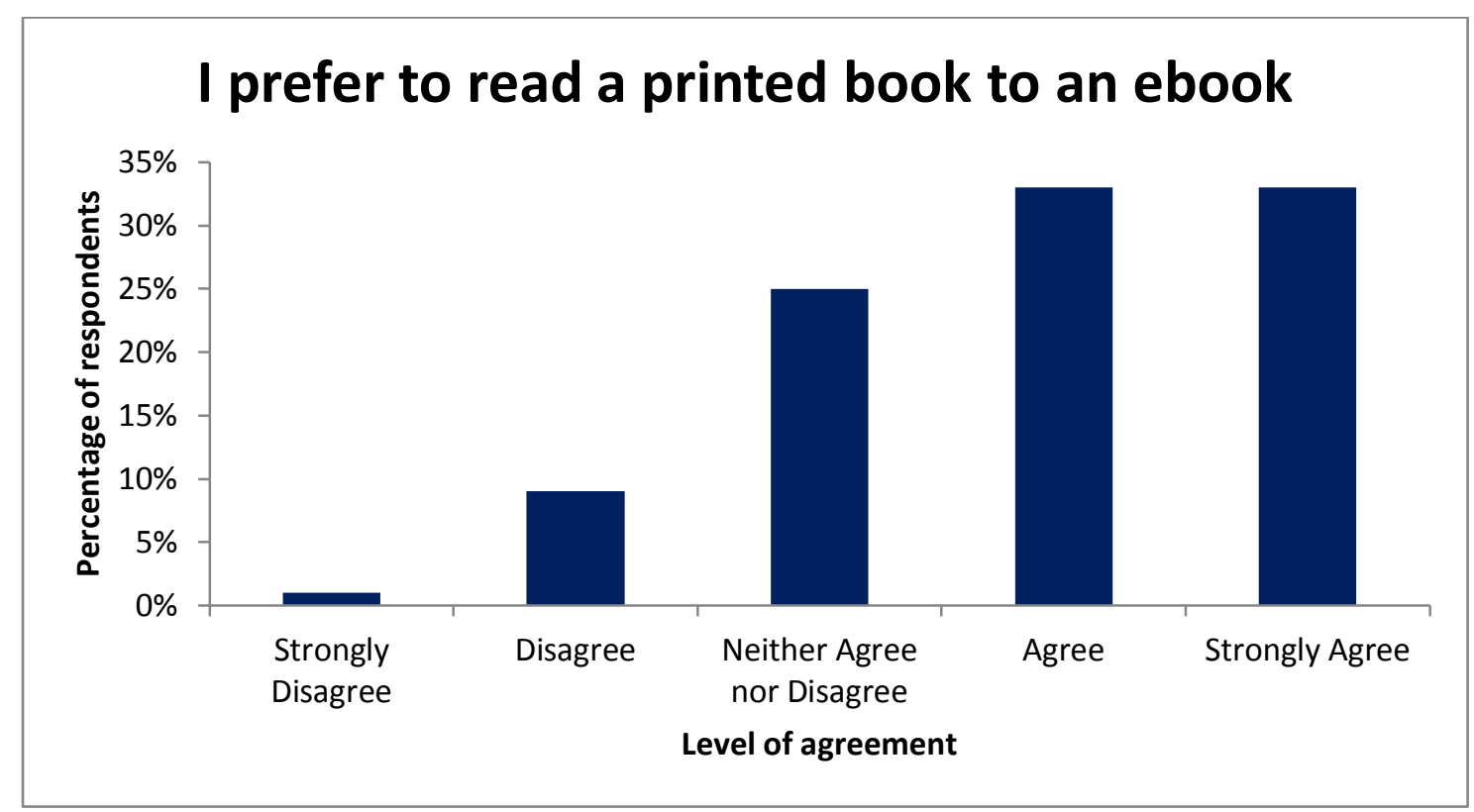


By grouping the responses by ebook reader ownership (specifically for reading ebooks) and graphing the results we can see the differing responses between the two groups. $77 \%$ of respondents who do not own an ebook reading device Agree or Strongly Agree to the statement "I prefer to read a printed book to an ebook" whereas $46 \%$ of respondents who do own one Agree or Strongly with the statement.

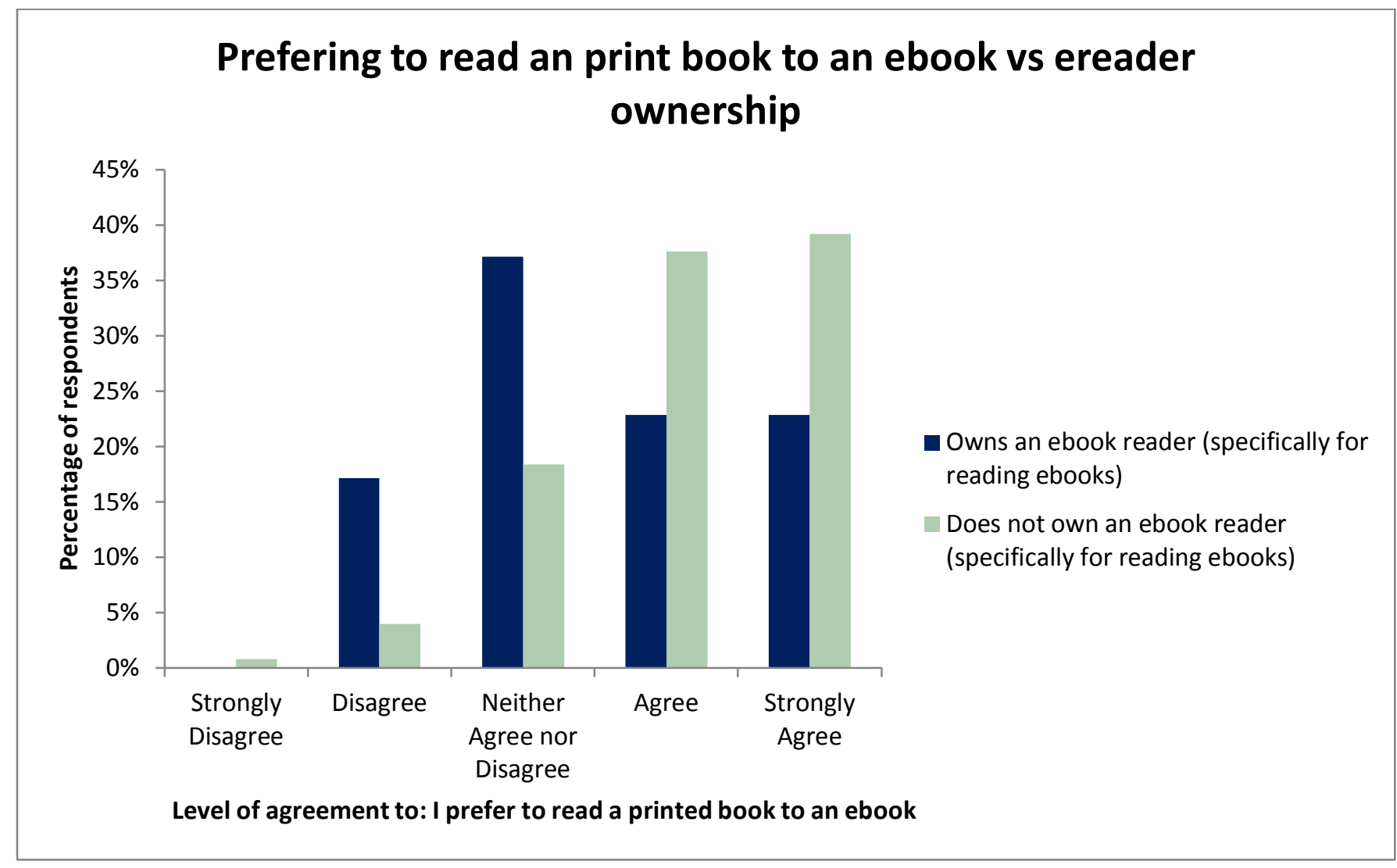

\section{My library has a great stock of ebooks.}

Looking at only respondents from libraries that offered ebooks, there were 184 responses. The median is Neither Agree nor Disagree. 1\% (2) of respondents answered Strongly Disagree to this statement, 30\% (55) Disagree, 34\% (62) Neither Agree nor Disagree, 32\% (58) Agree and 4\% (7) Strongly Agree. 


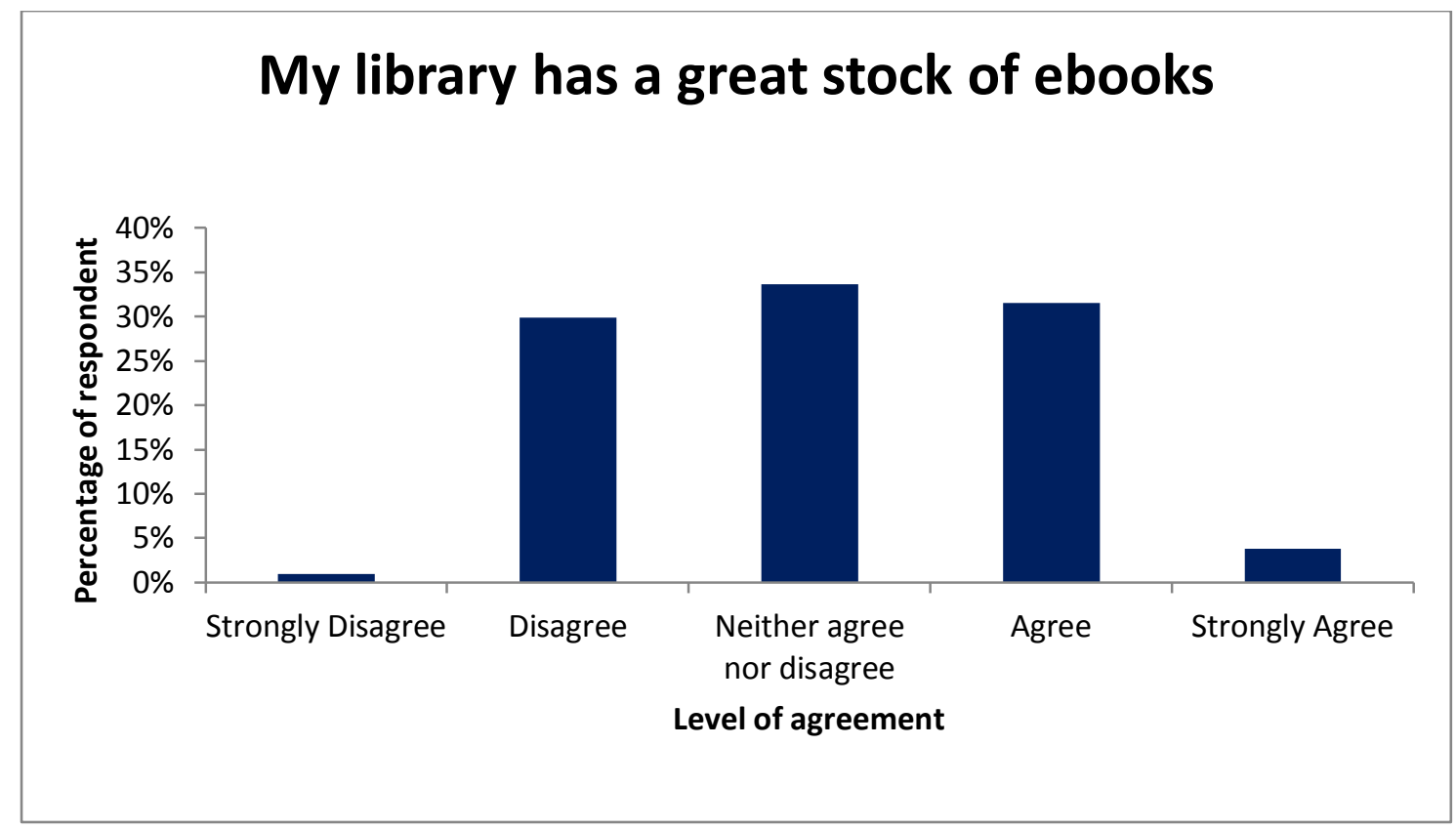

How frequently do you tell patron that your library offers ebooks? Looking at only respondents from libraries that offered ebooks, there were 182 responses. The median response was Frequently.

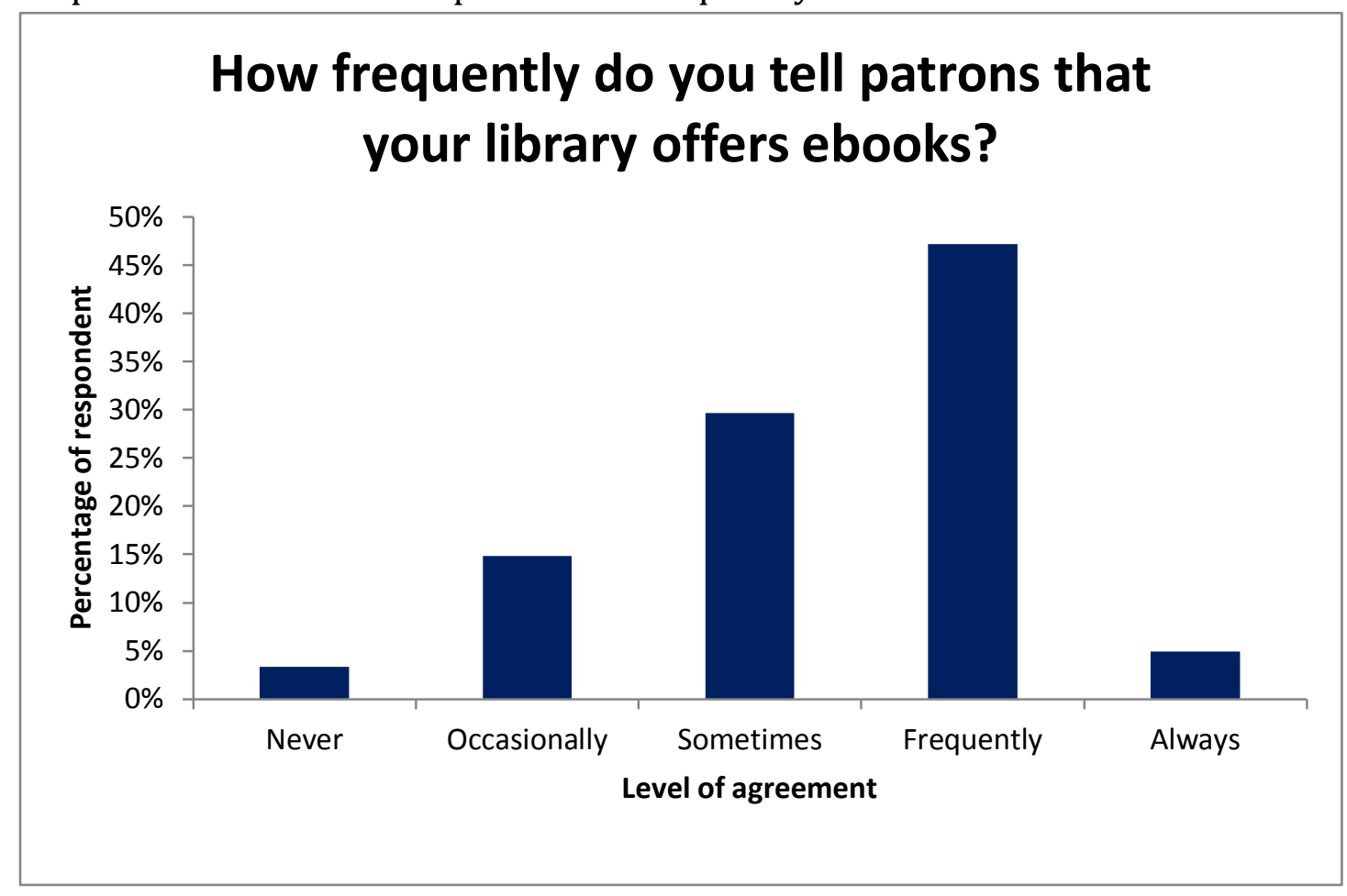

The graph below looks at whether there is a relationship between a respondent's opinion of library stock and the frequency with which the respondent tells patrons that their library offers ebooks.

Only respondents who answered both questions and who worked at libraries that offered ebooks were graphed. 
To make this graph the responses to the statement "My library has a great stock of ebooks" was divided into 3 categories 1) Strongly Disagree \& Disagree 2) Neither Agree Nor Disagree and 3) Agree or strongly agree.

Each of these three categories responses to the question "How frequently do you tell patrons that your library offers ebooks?" was graphed.

However, based on the graph below, there did not appear to be a relationship between a respondent's opinion of their ebook stock and the frequency of which they tell patrons that their library offers ebooks.

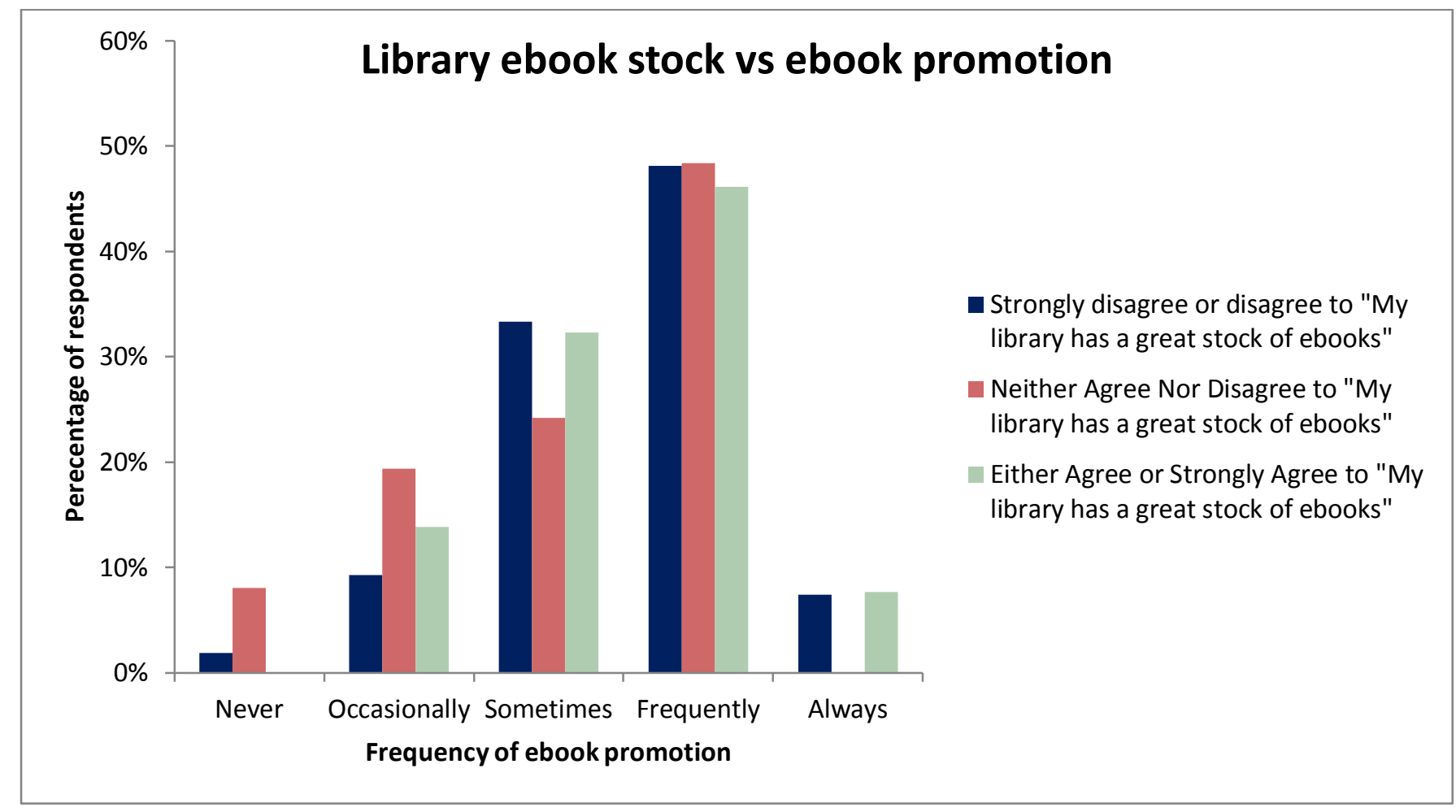

The graph below looks at whether there is a relationship between enjoyment of helping patrons with technical questions about ebooks and ereaders and the frequency with which the respondent tells patrons that their library offers ebooks.

To make this graph the responses to the statement "I enjoy helping patrons with technical questions about ebooks or ereaders." was divided into 3 categories 1) Strongly Disagree \& Disagree 2) Neither Agree Nor Disagree and 3) Agree or strongly agree.

Only respondents who answered both questions and who worked at libraries that offered ebooks were graphed.

Each of these three categories responses to the question "How frequently do you tell patrons that your library offers ebooks?" was graphed. 
Based on the graph below, respondents who agreed or strongly agreed to the statement "I enjoy helping patrons with technical questions about ebooks or ereaders" told patrons that their library offered ebooks more frequently.

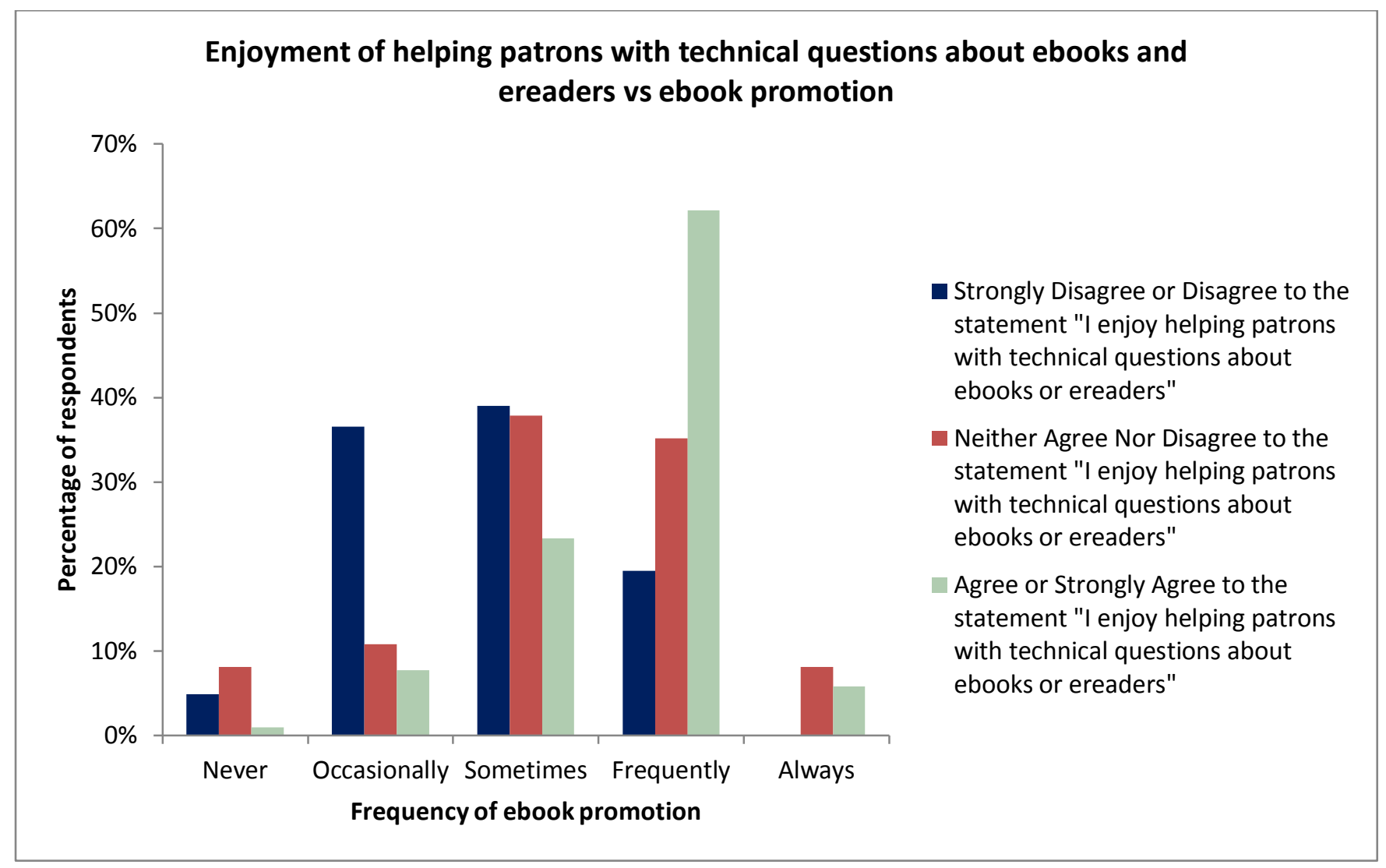

\section{Ebook licensing terms restricts the stock of ebooks available at my library}

Looking at only respondents from libraries that offered ebooks, there were 182 responses, the median response was Agree which 43\% (78) of respondents selected. $37 \%$ (68) selected strongly agree, which means $80 \%$ (146) of respondents answered Agree or Strongly Agree. 19\% (34) responded Agree nor Disagree and 1\% (2) answered Disagree. 


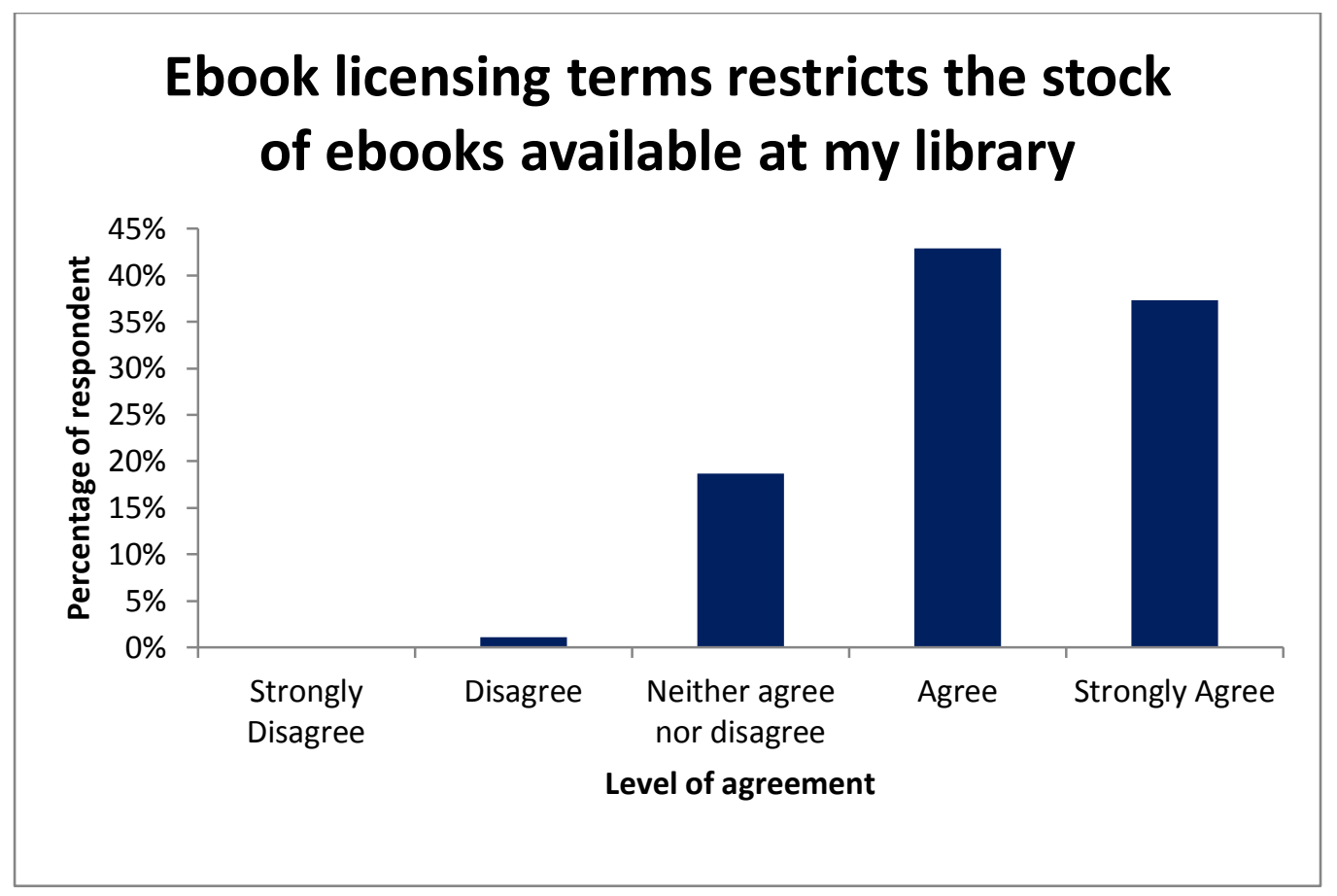

\section{Does your library offer staff training on how to borrow ebooks?}

Looking at only respondents from libraries that offered ebooks, there were 182 responses. 152 respondents said Yes (84\%), 20 respondents said No (11\%) and 10 said Don't know (5\%).

\section{Have you had training on how to borrow ebooks?}

Looking at only respondents from libraries that offered ebooks and also offered staff training, there were 154 responses. 127 answered Yes (82\%) and 27 (18\%) answered No.

If you add the 20 respondents who said that their library does not offer staff training on how to borrow ebooks, the 10 respondents that do not know if their library offers ebook training and the 27 respondents who have not had the offered training, 31\% of library staff surveyed working at libraries which offer ebooks have not been trained on how to borrow them.

This graph compares library staff surveyed who have had training on how to borrow ebooks compared to those who have not, and how much they agree with the statement "I enjoy helping patrons with technical questions about ebooks and ereaders".

The graph shows that the library staff surveyed who have had training on how to borrow ebooks are more likely to Agree or Strongly Agree to the statement that they enjoy helping patrons with technical questions about ebooks and ereaders. 


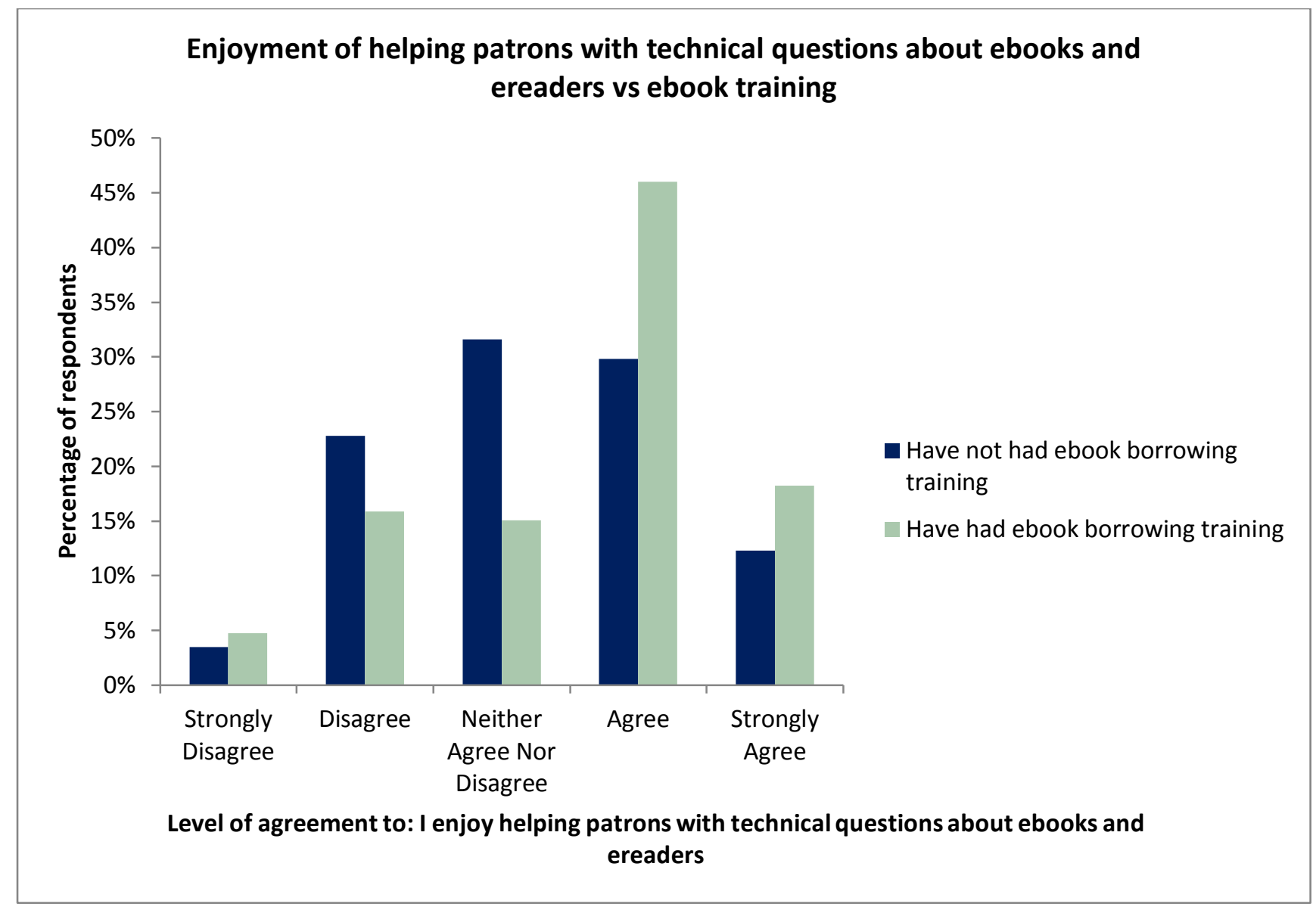

\section{How many hours do you work per week?}

Due to an error in survey design this question was only offered to respondents whose libraries offer training on how to borrow ebooks. 159 respondents answered this question. 92\% (147) of respondents worked 20 or more hours a week, and 8\% (12) worked less than 20 .

\section{Where is your library located?}

Due to an error in survey design this question was only offered to respondents whose libraries offer training on how to borrow ebooks. There were 158 respondents. 54\% (85) of respondents were located in a Large city, 27\% (42) Medium City, 16\% (25) Small town and 4\% (6) were located rurally. 


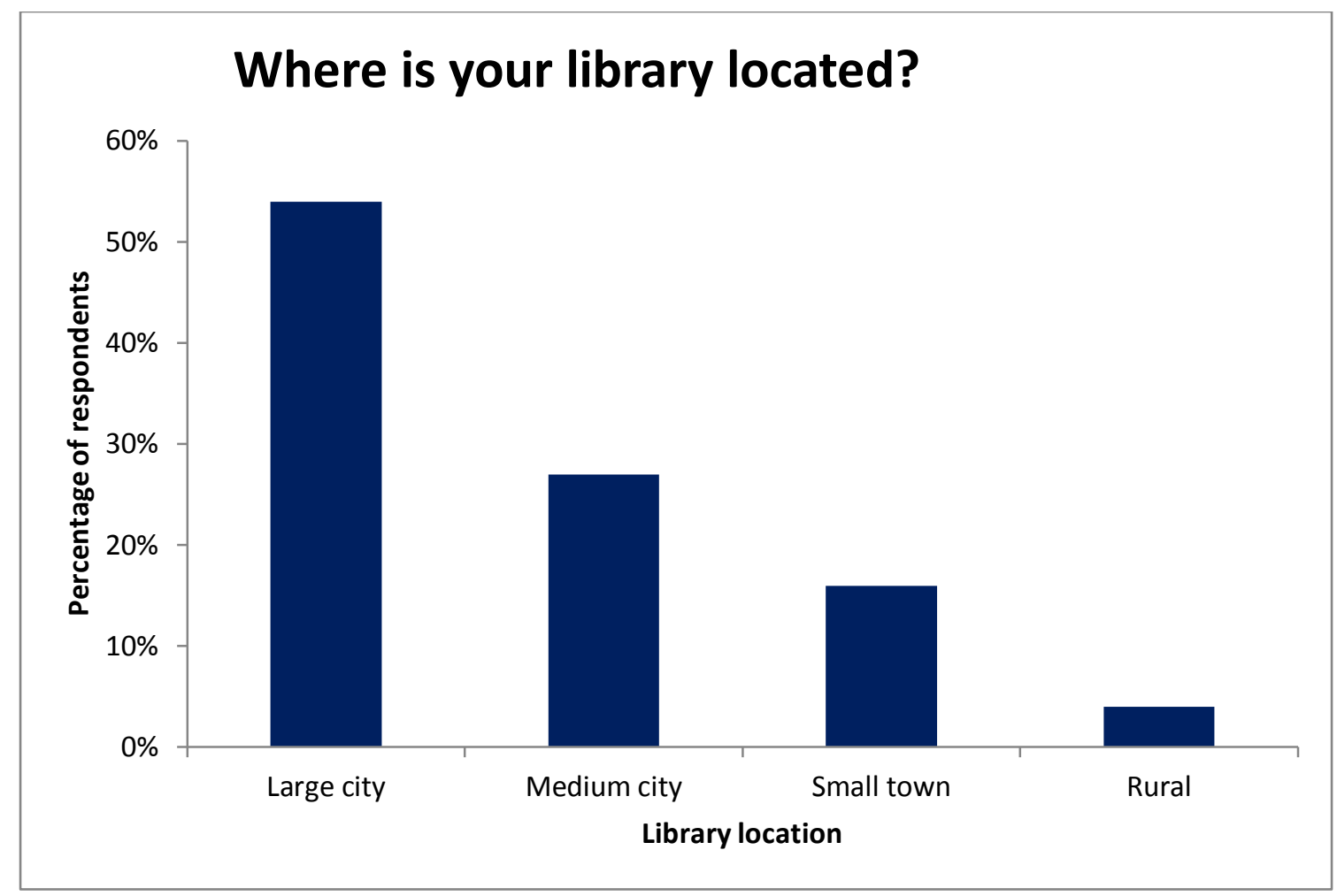

What is your main job function?

Due to an error in survey design this question was only offered to respondents whose libraries offer training on how to borrow ebooks. There were 159 respondents.

\begin{tabular}{|l|r|r|}
\hline $\begin{array}{l}\text { Customer Service (including circulation, issues and } \\
\text { enquiries) }\end{array}$ & 67 & $42 \%$ \\
\hline Library Management & 35 & $22 \%$ \\
\hline Customer Specialist/ Outreach & 15 & $9 \%$ \\
\hline IT and/or Library Website & 10 & $6 \%$ \\
\hline Purchasing & 10 & $6 \%$ \\
\hline Other & 6 & $4 \%$ \\
\hline Cataloguing & 3 & $2 \%$ \\
\hline Interloans & 3 & $2 \%$ \\
\hline Heritage & & \\
\hline
\end{tabular}




\section{Additional comments about ebooks}

There were many interesting additional comments written in the text box at the end of the survey. The main themes and concerns are summarised.

The biggest issue noted was that libraries only have a limited ebook range available for borrowing due to publisher restrictions and licensing issues.

Many library staff noted in this section that borrowing ebooks from the library is a difficult process overall and is confusing for patrons. A couple of library staff noted that only some library staff within a library are confident helping people with ebook enquiries, especially technical questions.

The non-compatibility of the Kindle ereader with library ebooks is considered a big issue. Amazon ebooks bought via the Kindle were noted to be much easier to download compared to borrowing an ebook from the library. Library staff noted that many patrons are surprised that Kindle ereaders are not compatible.

A recurring theme was that libraries need to embrace ebooks to remain current.

A different recurring theme was that ebooks complement but do not and should not replace other library items.

Library staff really appreciate the ability to change the font size of ebooks, so they are accessible to people who cannot read smaller print.

Many library staff noted that the ability to borrow ebooks "anywhere" is a big advantage to users, with one noting ebook lending has "enormous geographic access" potential.

A few library staff noted that their library was planning to offer ebooks soon (although these library staff could potentially be from the same library).

One librarian noted "we have had several public training sessions where people bring their devices and share information", another noted that their library has information sessions for people thinking of buying an ereader where patrons can come and try out a few different sorts of ereaders, whereas another noted they have one-to-one training where needed and another similarly noted "Library members frequently require oneon-one training to set up their mobile device ready to download eBooks using OverDrive."

Two library staff noted that their libraries offered ebooks through an Overdrive consortium.

Two library staff noted they have multifunctional tablets rather than specific ereaders.

One librarian noted they do not offer ebooks due to the initial start-up cost, whereas another noted that the price of ebooks is a factor that limits the stock they can offer. 
Another theme was that is that it is still early days for ebook borrowing and how the lending and licensing situation evolves remains to be seen.

Also, there were some interesting comments that could not be summarised into larger themes:

"NZ needs its own ebook platform for a NZ Digital library for all libraries' members to borrow from."

"Government digitising projects i.e.: Cyclopedia of New Zealand need now to be available on e-book - this type of change would maximise availability of material otherwise e-book compatible and broaden the range of material available to e-book holders."

"They are great for kids with dyslexia esp. if they [the ereaders] have the reading aloud function."

"The training we have had is just on the ebooks website."

"Still prefer a paper book for daily reading [as opposed to travelling] because you can flip back and forwards. I often check the end of the book when I'm partway through and this isn't so easy for me in an ebook."

"I think many people reject the idea of ebooks and using ereaders because they feel they are not actually reading a real book. I have noticed though that these people have never used an ereader and, when they do, their opinions change drastically."

\section{DISCUSSION OF LIMITATIONS}

As survey participants were invited to do an online survey about ebooks by email, it is possible that respondents who were interested in ebooks were more likely to complete the survey.

Additionally, there will be some New Zealand public library staff who are not signed up to NZ-Libs, PUBGSIG or do not work at Wellington City Libraries. These library staff may have different opinions about ebooks.

There were 202 respondents included in this survey in total to form the results, although not every respondent answered every question. While this number gives a good indication on the opinions of New Zealand public library staff, a larger sample could potentially show different trends.

Due to a design error in the survey, library staff whose libraries did not offer ebook training missed out on the opportunity to answer the three questions near the end of the survey being, how many hours they worked per week, where their library was located, and what their main job function was, although they did get the opportunity to make any additional comments about ebooks. 


\section{DISCUSSION}

The majority of library staff surveyed have read at least one ebook in the past 12 months

$63 \%$ of New Zealand public library staff surveyed have read at least one ebook in the past year. 23\% of Americans over the age of 16 have read an ebook in the past 12 months. (Rainie \& Duggan, 2012). If the American public is comparable to the New Zealand public, then New Zealand public library staff are reading, or have at least tried reading, ebooks at a much higher rate.

\section{$\mathbf{3 5 \%}$ of library staff surveyed own an ereader specifically for reading ebooks.}

$35 \%$ of New Zealand public library staff surveyed own an ebook reading device specifically for reading ebooks compared with $19 \%$ of the American public aged 16 and over.

$55 \%$ of respondents who did not own an ebook reading device had not read any ebooks in the past 12 months whereas only $4 \%$ of those who owned an ebook reading device had not read any ebooks in the past 12 months.

$50 \%$ of respondents who owned an ebook reading device have read more than 5 ebooks in the past year whereas $15 \%$ of respondents who do not own an ebook reading device have read more than 5 ebooks in the past year.

This may mean that library staff who like ebooks have bought ereaders specifically for reading ebooks, or that library staff who like to read more overall have bought ereaders, or that library staff who have read ebooks on tablets or computers are discouraged from doing so too often due to reading from a screen.

\section{$\mathbf{9 3 \%}$ of library staff surveyed work at a library that offers ebooks, $9 \%$ work at a} library that lends ereaders.

93\% of library staff surveyed work at public libraries that offer ebooks, however only $9 \%$ work at places that lend ebook readers. As identified by the COSLA (2012) this potentially has implications for widening the digital divide, as only people who can afford ebook reading devices will be able access ebooks and also be able to learn how to use them.

\section{Library staff surveyed think offering ebooks is important}

93\% of respondents Agree or Strongly Agree with the statement that it is important for public libraries to offer ebooks. The median response fell between Agree and Strongly Agree. This is emphasised in the additional text responses where a strong theme was that libraries need to embrace ebooks to remain current. This is also in-line with finding from OCLC (2011) that found providing access to ebooks is a top priority for American public library staff. 


\section{Many library staff surveyed enjoy helping patrons with technical questions about ebooks or ereaders but not all}

"I enjoy helping patrons with technical questions about ebooks or ereaders" while the median response to this question was agree, 5\% answered Strongly Disagree , 18\% Disagree, 20\% Neither Agree nor Disagree, 41\% Agree, and 16\% Strongly Agreed.

Survey respondents who owned an ereader specifically for reading ebooks, or who had received training on how to borrow ebooks, were more likely to Agree or Strongly Agree to this statement.

To increase the amount of public library staff that would agree to the statement "I enjoy helping patrons with technical questions about ebooks or ereaders", libraries could ensure that all staff receive training on how to borrow ebooks. Additionally, while purchasing every librarian an ereader may not be practicable, libraries could potentially purchase a selection of ereaders that staff can borrow to practise with.

Respondents who agreed or strongly agreed to the statement "I enjoy helping patrons with technical questions about ebooks or ereaders" told patrons their library offered ebooks more frequently. As such making sure library staff are confident technically may lead to increased promotion which could lead to increased usage of ebook collections.

\section{Most library staff surveyed think the increasing popularity of ebooks is good for libraries}

While the median answer was Agree to the statement "The increasing popularity of ebooks is good for libraries", more respondents Neither Agreed nor Disagreed with the statement than Strongly agreed with it. This shows that some respondents have concerns about how ebooks will impact on the future of libraries.

\section{Incompatible file formats}

The median response was Agree to "incompatible ebook file formats are a frequent problem for library patrons." 58\% of respondents answered Agree or Strongly Agree to this statement showing that although the majority of respondents agreed, many did not.

\section{Library staff surveyed think it is important that ebooks can be borrowed anytime} 91\% of respondents answered Agree or Strongly Agree to the statement "The ability of ebooks to be borrowed 24/7 is important." This may be because as ebooks are offered all the time, even when the library is closed, it increases patron's accessibility to the library collection.

\section{Most library staff surveyed think the searchability of ebooks is useful}

The median response to the statement "The searchability of ebooks is useful" is Agree. $76 \%$ of respondents answered Agree or Strongly Agree. While this is a big majority, it is comparatively less than the $91 \%$ Agree or Strongly Agree that the statement "the ability of ebooks to be borrowed 24/7 is important" received. Studies of academic library users 
showed searchability to be a very important feature of ebooks, perhaps in a public library where fiction has a high circulation, it is considered relatively less important.

\section{Library staff surveyed think the portability of ebooks is useful}

The median response to the statement "the portability of ebooks is useful" was Strongly Agree. 96\% of respondents answered either Agree or Strongly Agree to this statement. Only 4\% answered neither Agree nor Disagree and no respondents disagreed with this statement. This is consistent to what Salomon (2009), Borchert et al. (2009) and Richardson and Mahmood (2012) found.

\section{Library staff surveyed think the ability to customise ebooks is useful}

The median response to the statement "the ability to customise ebooks is useful e.g. change font size, add bookmarks etc." was Strongly Agree. 95\% of respondents answered Agree or Strongly Agree to this statement. Furthermore, in the text response question where respondents could add their own comments it was noted that the reason library staff appreciate this was the ability to change font size increases accessibility to the library's collection for those patrons who cannot read small print.

\section{Many library staff surveyed would prefer to read a printed book to an ebook but not all}

The median response to the statement "I prefer to read a printed book to an ebook" was Agree. $66 \%$ of respondents either answered Agree or Strongly Agree. One librarian noted that they like books because they can flip backwards and forwards more easily than a printed book.

$77 \%$ of respondents who do not own an ebook reading device (specifically for reading ebooks) answered Agree or Strongly Agree to the above statement whereas $46 \%$ of respondents who do own one Agree or Strongly with the statement.

\section{Library staff surveyed have varying responses to the statement "My library has a great stock of ebooks."}

The median response to this statement Neither agree nor disagree. $30 \%$ of respondents answered Disagree to this statement, 34\% answered Neither Agree nor Disagree and 32\% answered Agree.

One potential reason that the library staff surveyed did not agree with this statement is that they feel ebook licensing terms restrict what libraries can purchase, this is looked at below. Another potential reason is the expense of ebooks, which one librarian noted in the additional comments section that this was the case for his or her library.

\section{Frequency of ebook promotion by library staff surveyed}

The median response was Frequently. When the frequency of promotion was graphed against the library staff responses to "My library has a great stock of ebooks" there did not appear to be any relationship. 
One factor that did affect respondents' frequency of promotion was that respondents who agreed or strongly agreed to the statement "I enjoy helping patrons with technical questions about ebooks or ereaders" told patrons that their library offered ebooks more frequently.

This could be because they are more confident talking about ebooks, or it could be that they like ebooks in the first place, leading to them being more confident about ebooks, and therefore want to tell people about them.

The majority of library staff surveyed agree that ebook licensing terms restricts the stock of ebooks available at their library

$80 \%$ of respondents answered Agree or Strongly Agree to the statement "ebook licensing terms restricts the stock of ebooks available at my library." $19 \%$ of respondents answered Agree nor Disagree and 1\% answered Disagree.

For ebooks to be truly successful in New Zealand public libraries, issues around licensing terms will have to be resolved. In the additional comments section of the survey, the biggest issue noted was that libraries only have a limited ebook range available for borrowing due to publisher restrictions and licensing issues.

\section{Ebook training for library staff surveyed}

$31 \%$ of library staff surveyed working at libraries which offer ebooks have not had training on how to borrow them.

Library staff surveyed who have had training on how to borrow ebooks are more likely to Agree or Strongly Agree to the statement that they enjoy helping patrons with technical questions about ebooks and ereaders. As such, in the interests of providing the best customer service, libraries should ensure all library staff receive training on how to borrow ebooks. If the training is offered online, then libraries should ensure that the library staff undertake this training.

\section{Hours of work, job function and location}

These questions were included to get a break down of the demographic of survey respondents, although due to the survey design ended up only showing the demographic of survey respondents who worked in libraries that offered ebook borrowing training. 92\% (147) worked 20 hours or more a week, 54\% (85) were from a large city and $42 \%$ (67) had the main job function of customer service.

\section{SUGGESTIONS FOR FURTHER RESEARCH}

Based on the results, there are several interesting areas which could be explored with further research.

A potential area for further study could be looking at the ebook reading habits of the New Zealand public, including what people are using to read ebooks, i.e. what different 
ereaders, what tablets, if they use computers at all. Additionally it would be interesting to see if people that read more overall read more ebooks.

Two survey respondents in the additional comments section of the survey noted that their libraries offered ebooks through an Overdrive consortium. It would be interesting to research how these consortiums are implemented and what the advantages and disadvantages are to these, for both libraries and patrons.

$9 \%$ of library staff in the survey indicated that their libraries lend ereaders. Research on how these New Zealand public libraries implemented lending ereaders and the outcomes of it, i.e. if it has been successful, how much has it cost the library, would be very useful in informing other libraries decisions as to whether they want to implement an ereader lending scheme or not.

91\% of respondents answered Agree or Strongly Agree to the statement "The ability of ebooks to be borrowed 24/7 is important ". It would be interesting to research further as to why they agree with this statement, is it for the sheer convenience of the borrower or is it for borrowers who cannot make it to the library during library opening hours? It would also be valuable to know if the New Zealand public similarly agrees to this statement.

Another valuable area for further study would be to survey people who use the large print collection of the library to see if the ability to adjust font size of ebooks is valuable to them, as well as surveying patrons generally to see if they do or would adjust the font size on ebooks.

Lastly, it will be interesting to see how library staff feel in the future about the topics covered in this research project, as ebook technology changes so might the opinions of library staff.

\section{CONCLUSION}

Public library staff in New Zealand feel it is important for libraries to offer ebooks to remain current, yet some hesitation remains as to whether they will impact positively on libraries.

There is ongoing concern over the impact publisher's licensing conditions have on New Zealand public libraries ebook stock and it will be interesting to see what happens with ebook licensing in the future.

Library staff surveyed agreed that features such as portability, ability to customise, 24/7 availability and searchability were useful features of ebooks, in that order. Research on groups of users, such as those who cannot come to the library, or those who use the large print collection, could show if ebooks had the potential to benefit them more than the print collection does. 
A small majority of librarians enjoy helping patrons with technical questions about ebooks, this majority may increase as the technology becomes more familiar to both library staff and patrons, or it may increase if ebook lending becomes more simplified.

There appeared to be a relationship between enjoying technical questions about ebooks and having had training on how to borrow ebooks. Public libraries should look at both the training they offer and if confidence around ebook technology is something that would benefit them to address.

Overall, this research offers an interesting look into the current opinions and thoughts of New Zealand public library staff on ebooks; these will undoubtedly change in time along with the evolving ebook situation. 


\section{Bibliography}

Aptara. (2012). Revealing the business of ebooks. Retrieved January 20, 2013, from http://ww3.aptaracorp.com/lp/landingpages/4thebooksurveyregister.html

Borchert, M., Hunter, A., Macdonald, D., \& Tittel, C. (n.d.). A Study on Student and Staff Awareness, Acceptance and Usage of E-books at two Queensland Universities. Retrieved August 22, 2011, from http://www.informationonline.com.au/sb_clients/iog/data/content_item_files/000001/PresentationA1. pdf

COSLA. (2010). COSLA: eBook Feasibility Study for Public Libraries. Retrieved August 8, 2012, from http://www.cosla.org/documents/COSLA2270_Report_Final1.pdf

Crawford, S., Couper, M., \& Lamias, M. (2001). Web Surveys: Perceptions of Burden. Social Science Computer Review, 19(2), 146-162.

Davidson, C., \& Tolich, M. (2003). Social Science Research in New Zealand. Auckland: Pearson Education New Zealand Limited.

Duncan, R. (2010). Ebooks and Beyond: The Challenge for Public Libraries. Australasian Public Libraries and Information Services, 23(2), 44., 23(2), 44-55.

ebrary. (2008). 2008 Global Student E-book Survey. Retrieved September 16, 2011, from http://www.ebrary.com/corp/collateral/en/Survey/ebrary_student_survey_200 8.pdf

Hadro, J. (2011). HarperCollins Puts 26 Loan Cap on Ebook Circulations. Retrieved February 6, 2013, from Library Journal: http://www.libraryjournal.com/lj/home/889452264/harpercollins_puts_26_loan_cap.html.csp

Hoffert, B. (2012). Book Buying Survey 2012: Book Circ Takes A Hit. Retrieved September 12, 2012, from http://lj.libraryjournal.com/2012/02/library-services/bookbuying-survey-2012-book-circ-takes-a-hit/

Hoffman, J., Bertot, J. C., \& Davis, D. M. (2012). Libraries Connect Communities: Public Library Funding \& Technology Access Study 2011-2012. Retrieved from http://viewer.zmags.com/publication/4673a369

Kelley, M. (2012 ). Random House Reaffirms Commitment to Library Ebook Lending While Raising Prices to Wholesalers. Retrieved February 6, 2013, from Library Journal: http://www.thedigitalshift.com/2012/02/ebooks/random-house-reaffirmscommitment-to-library-ebook-lending-while-raising-prices-to-wholesalers/

Library Association of New Zealand Aotearoa. (n.d.). PUBSIG. Retrieved February 1, 2013, from LIANZA: http://www.lianza.org.nz/community/group/pubsig 
Library Journal. (2012). Ebook Usage in U.S Public Libraries.

Maloney, J. (2012). Libraries Cut E-Book Deal With Penguin. Retrieved February 6, 2013, from The Wall Street Journal:

http://online.wsj.com/article/SB100014240527023048987045774791740512 16172.html

NZ-Libs. (n.d.). About NZ-Libs. Retrieved February 1, 2013, from NZ-Libs: http://lists.vuw.ac.nz/mailman/listinfo/nz-libs

OCLC. (2011). A Snapshot of Priorities \& Perspectives U.S. Public Libraries. Retrieved January 30, 2013, from http://www.oclc.org/reports/us-publiclibraries/214758usb-A-Snapshot-of-Priorities-and-Perspectives.pdf

OverDrive. (2013). Device Resource Center. Retrieved January 27, 2013, from http://www.overdrive.com/resources/drc/

Publishers Weekly. (2012). AAP Estimates: E-book Sales Rose 117\% in 2011 as Print Fell. Retrieved January 21, 2013, from http://www.publishersweekly.com/pw/bytopic/industry-news/financial-reporting/article/50805-aap-estimates-e-booksales-rose-117-in-2011-as-print-fell.html

Rainie, L., \& Duggan, M. (2012). E-book Reading Jumps; Print Book Reading Declines. Retrieved January 25, 2013, from http://libraries.pewinternet.org/files/legacypdf/PIP_Reading\%20and\%20ebooks_12.27.pdf

Raphael, M. (2012). Ebooks: Promising New Conversations. Retrieved February 6, 2013, from American Libraries: http://americanlibrariesmagazine.org/econtent/ebooks-promising-new-conversations

Reid, C., \& Milliot, J. (2012). Tablet Use, E-book Sales Grow Beyond Amazon, Nook. Retrieved January 21, 2013, from http://www.publishersweekly.com/pw/bytopic/digital/retailing/article/54872-tablet-use-e-book-sales-grow-beyondamazon-nook.html

Richardson, J. V., \& Mahmood, K. (2012). Ebook Readers: User Satisfaction and Usability issues. Library Hi Tech, 30(1), 170 - 185.

Salomon, N. J. (2009). North Carolina Public Librarians Opinions Regarding Electronic Texts. Retrieved October 17, 2011, from http://ils.unc.edu/MSpapers/3520.pdf

Simon, M. K., \& Goes, J. (2011). Dissertation and Scholarly Research: Recipes for Success: 2011 Edition. Seattle, WA: Dissertation Success, LLC.

Staiger, J. (2012). How Ebooks are Used. Reference \& User Services Quarterly, 51(4), 355365. 
Vasileiou, M., \& Rowley, J. (2010). Marketing and Promotion of Ebooks in Academic Libraries. Journal of Documentation, 67(4), 624-643.

Waimakariri. (n.d.). Ebooks and Ereaders. Retrieved January 27, 2013, from http://libraries.waimakariri.govt.nz/books_resources/ebooks-ereaders.aspx

Zickuhr, K., Rainie, L., Purcell, K., Madden, M., \& Brenner, J. (2012). Libraries, patrons, and e-books. Retrieved from http://libraries.pewinternet.org/files/legacypdf/PIP_Libraries_and_Ebook_Patrons\%206.22.12.pdf 


\section{APPENDIX A}

Participant Information Sheet: What are the opinions of public library staff on ebooks?

Researcher: Megan Percy, School of Information Management, Victoria University of Wellington

I am a Master of Information Studies student at Victoria University of Wellington. As part of this degree, I am undertaking a research project examining the opinions of public library staff on ebooks. The School of Information Management Human Ethics Committee has approved this survey.

I am inviting New Zealand public library staff to participate in the project by completing an online survey. If you agree to participate, you will be asked to complete an anonymous survey, which will take about ten minutes to complete. Your submission of the survey is your consent to participate in this project.

Responses to the survey questions will form part of my written report and may also be used in articles published in academic journals and presented at conferences. Because the survey is anonymous, it will not be possible for you to be identified in any of those venues. All information collected will be kept confidential in a locked filing cabinet and/or password protected computer files. No other person besides me and my supervisor, Brenda Chawner, will have access to the data.

The project will be submitted for marking to the School of Information Management and project will be deposited in the Victoria University Library. Responses will be destroyed two years after the end of the project. A summary of the results will be posted to the PUBSIG and NZLIBS email lists.

If you have any questions or would like to receive further information about the project, please contact me, Megan Percy at percymega@myvuw.ac.nz or my supervisor, Brenda Chawner, at Brenda.chawner@vuw.ac.nz, at the School of Information Management at Victoria University, P O Box 600, Wellington, 6140.

One lucky person who completes this survey will win a $\$ 50$ MightyApe voucher. This will be chosen randomly. Your email address will be required so that you can be notified if you win. Your email address however will be removed before the data is analysed to preserve your anonymity.

How many ebooks have you read in the past 12 months?

0

1-5

$5-10$

$10-20$

$20+$

Do you own an ebook reading device? (Specifically for reading ebooks)

Yes

No 
Does your library offer ebook lending?

Yes
No
Don't know

Does your library lend ebook readers?
Yes
- No
Don't know

Please indicate your level of agreement with each of the following:

It is important for public libraries to offer ebook lending

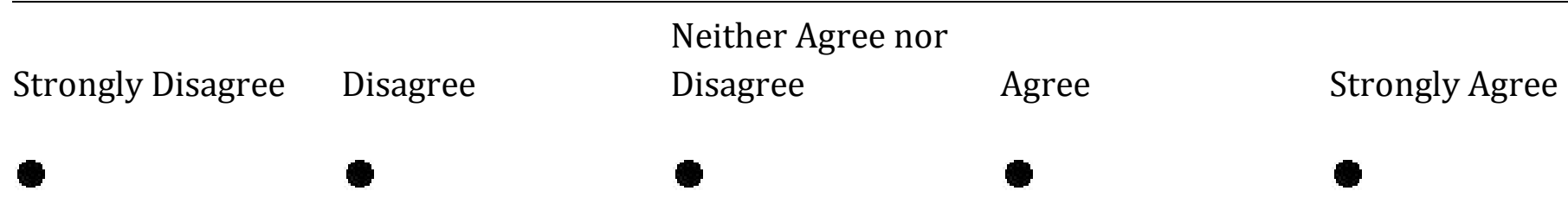

I enjoy helping patrons with technical questions about ebooks or ereaders

\begin{tabular}{|c|c|c|c|c|}
\hline & & Neither A & & \\
\hline Strongly Disagree & Disagree & Disagree & Agree & Strongly Agree \\
\hline
\end{tabular}

The increasing popularity of ebooks is good for libraries

Strongly Disagree Disagree

Neither Agree nor

Agree

Strongly Agree 


\section{Disagree}

The ability of ebooks to be borrowed 24/7 is important

Neither Agree nor

Strongly Disagree Disagree

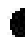

Disagree

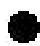

Agree Strongly Agree

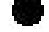

Incompatible ebook file formats are a frequent problem for library patrons

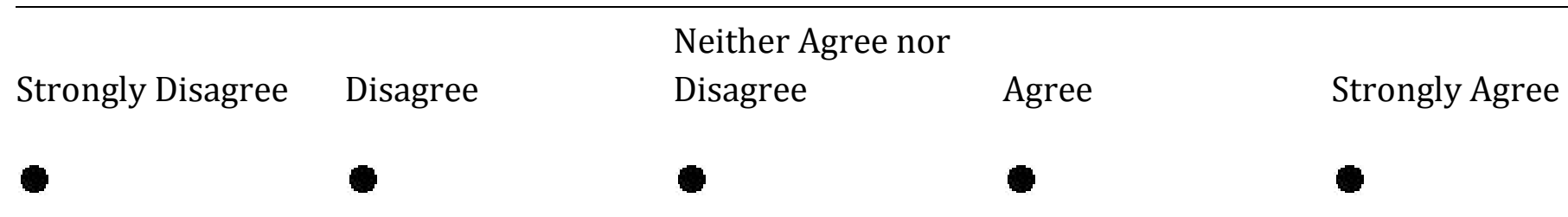

The searchability of ebooks is useful

Neither Agree nor

Strongly Disagree Disagree

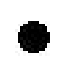

The portability of ebooks is useful

Neither Agree nor

$\begin{array}{llll}\text { Strongly Disagree } & \text { Disagree } & \text { Disagree } & \text { Agree } \\ & - & & \end{array}$

The ability to customise ebooks is useful e.g. change font size, add bookmarks etc

Neither Agree nor

Strongly Disagree

Disagree

Disagree

Agree

Strongly Agree 
I prefer to read a printed book to an ebook

\begin{tabular}{llll}
\hline & & Neither Agree nor & \\
Strongly Disagree & Disagree & Disagree & Agree \\
& & & Strongly Agree
\end{tabular}

My library has a great stock of ebooks

\begin{tabular}{llll}
\hline & & Neither Agree nor & \\
Strongly Disagree & Disagree & Disagree & Agree \\
& - & & Strongly Agree
\end{tabular}

How frequently do you tell patrons that your library offers ebooks?

\begin{tabular}{|c|c|c|c|c|}
\hline Never & Occasionally & Sometimes & Frequently & Always \\
\hline
\end{tabular}

Ebook licensing terms restricts the stock of ebooks available at my library

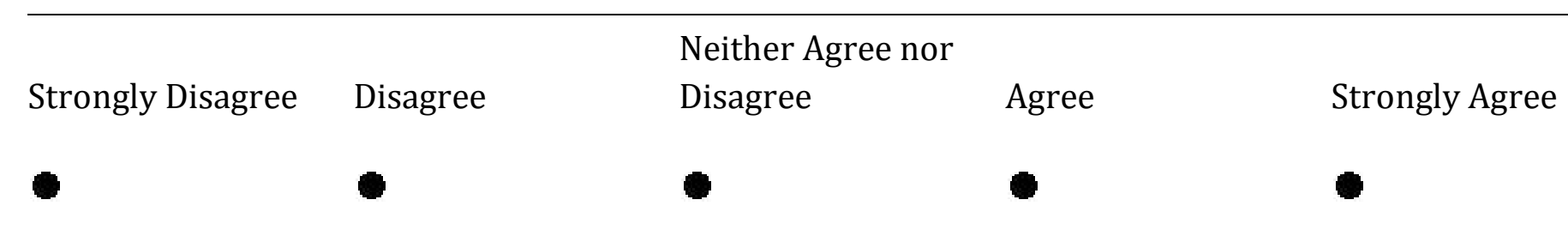

Does your library offer staff training on how to borrow ebooks?

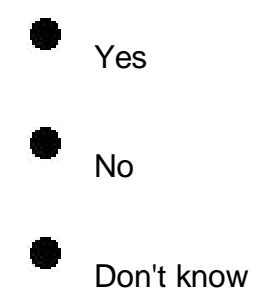


Survey Powered By Qualtrics

Have you had training on how to borrow ebooks?

Yes

No

How many hours do you work per week?

20 or more

Less than 20

Where is your library located?

Large city

Medium city

Small town

Rural

What is your main job function?

Cataloguing

- Customer service (including circulation, issues and enquiries)

Customer Specialist/ Outreach

Housebound

Interloans

IT and/or Library website 
Library management

Purchasing

Processing (of new materials)

Shelving

Other

Prefer not to state

Please make any additional comments about ebooks here.

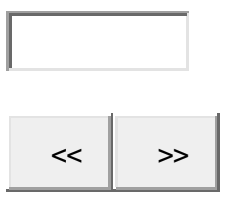

Survey Pow 


\section{APPENDIX B}

Subject: Survey invitation. Win a $\$ 50$ MightyApe voucher!

Hello,

I would like to invite all New Zealand public library staff to complete a survey about their opinions on ebooks. The survey will take about 10 minutes.

I am a postgraduate student at Victoria University. Data from the survey will be analysed for my Master of Information Studies research project on the opinions of New Zealand public library staff on ebooks. All responses are anonymous.

One email address will be selected randomly from everyone who completes the survey to win the MightyApe voucher. The email addresses will be removed before the data is analysed to preserve your anonymity.

If you have any questions about the survey please email me at percymega@myvuw.ac.nz or my supervisor, Brenda Chawner at Brenda.chawner@vuw.ac.nz

Please click the link below to complete the survey.

[Link]

Thank you for your time,

Megan Percy 